J Nat Prod. 2017 March 24; 80(3): 771-781. doi:10.1021/acs.jnatprod.6b01167.

\title{
Englerins: A Comprehensive Review
}

\author{
Zhenhua Wu $u^{\ddagger}$, Senzhi Zhao ${ }^{\ddagger} \S$, David M. Fash ${ }^{\ddagger}$, Zhenwu Li ${ }^{\ddagger}, \perp$, William J. Chain ${ }^{\ddagger}$, and John \\ A. Beutler ${ }^{*}, \dagger$ \\ †Molecular Targets Laboratory, Center for Cancer Research, National Cancer Institute, Frederick, \\ Maryland 21702, United States \\ ‡Department of Chemistry and Biochemistry, University of Delaware, Newark, Delaware 19716, \\ United States
}

\section{Graphical Abstract}

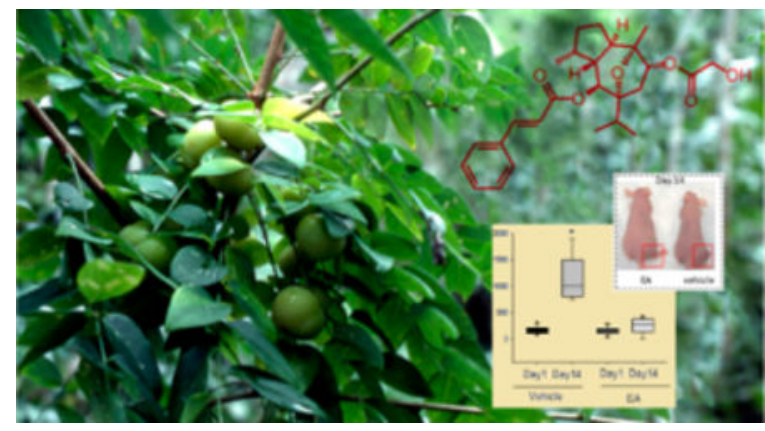

In the decade since the discovery of englerin A (1) and its potent activity in cancer models, this natural product and its analogues have been the subject of numerous chemical, biological, and preclinical studies by many research groups. This review summarizes published findings and proposes further research directions required for entry of an englerin analogue into clinical trials for kidney cancer and other conditions.

\section{INTRODUCTION}

The NCI 60 screening program was launched in 1989 with the goal of identifying drug candidates that would be selective for one of eight solid tumor panels. ${ }^{1,2}$ Since that time, a large number of pure compounds and natural product extracts have been screened, and while the NCI 60 has been extremely useful in identifying possible mechanisms of action, ${ }^{2}$ the original goal has been elusive. Clearly, the genetic diversity within tumor types was not appreciated at the time, and the selectivity of different agents tends to be based on the expression of specific protein targets rather than the organ from which the tumor originated.

"Corresponding Author Tel: 301-846-1942., beutlerj@mail.nih.gov.

\$Abzena-Bristol PA, 360 George Patterson Boulevard, Suite 101E, Bristol, Pennsylvania 19007, United States.

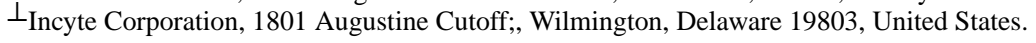

Notes

The authors declare the following competing financial interest(s): JAB, WJC and DMF have intellectual property rights in the subject matter of this review. 
However, one type of solid tumor, renal cancer, has been shown to be relatively homogeneous, with dysfunction in various components of glycolytic pathways such as von Hippel Lindau (VHL) playing a major role in the different subclasses of kidney cancer. ${ }^{3,4}$

Starting with this premise, we sought to identify natural product extracts that were selective for kidney cancer in the NCI 60 screen. Out of approximately 34000 NCI 60 dose-response tests of extracts, we rank-ordered all tests and then examined the dose-response curves of the 21 most selective extracts $(<0.1 \%)$ manually. ${ }^{5}$ Extracts were prioritized first by the magnitude of the $\mathrm{GI}_{50}$ range, i.e., the difference in potency between the least and most sensitive cell lines. Other considerations included the mass available for fractionation, the potency at mean $\mathrm{GI}_{50}$, and whether cytotoxic compounds had previously been isolated from the species, since our aim was to find novel compounds. For example, two marine mollusk extracts on the list had been previously found to contain well-known compound types, the staurosporines and lamellarins, ${ }^{6}$ and a marine sponge extract was found to contain jaspamide (jasplakinolide). However, the organic extract of the plant Phyllanthus engleri Pax (Euphorbiaceae) from Tanzania was at the top of the list, with a GI50 range of $3.94 \log 10$ units, essentially spanning the full range of the assay. We chose to pursue this extract by bioassay-guided fractionation, based on inhibition of renal cancer cell growth. We also examined the scientific literature on the plant to inform the process.

\section{Ethnomedical, Phytochemical, and Toxicological Information.}

The genus Phyllanthus is composed of 750-800 species and, thus, is one of the largest genera in the family Euphorbiaceae. ${ }^{7}$ As might be expected from such a large genus, it has a rich history of ethnomedical use, novel phytochemistry, and diverse bioactive constituents. $8-10$

The species $P$. engleri occurs throughout Tanzania and in many adjacent countries in East Africa. While only one pure compound, phyllanthol, had been previously identified from $P$. engleri, ${ }^{11,12}$ the use of the plant in traditional medicine in southern Africa and its toxicity were well documented. ${ }^{13}$ The most commonly reported medicinal use of the bark is for chest congestion. The method of administration is either by smoking the bark or as a cold water infusion in a gruel. ${ }^{14}$ Notably, P. engleri has been used to commit suicide by inhaling the fumes of burning root bark; ${ }^{15}$ however, the fruits and leaves are not generally considered poisonous. ${ }^{14}$ The root bark is reported to be available for medicinal use in herb markets in Tanzania.

A variety of animal experiments in South Africa in the 1930s showed that intravenous injection of the alcoholic extract was potently lethal to rabbits, with effects on respiration and the heart. However, the researchers were not able to demonstrate toxicity on inhalation of smoke from burning root bark in either guinea pigs or rabbits. ${ }^{15}$ Attempts to isolate the toxic principle provided a material that was claimed to be a glycoside; however, the researchers were not able to characterize it further. ${ }^{14}$ More recently, an extract of $P$. engleri was shown to be potently toxic to brine shrimp, with an $\mathrm{LC}_{50}$ value of $0.47 \mu \mathrm{g} / \mathrm{mL} .^{16}$ 


\section{Identification of Englerins A (1) and B (2).}

Initial bioassay-guided fractionation of the extracts of $P$. engleri root and stem bark at the NCI yielded a complex series of seven related chlorinated sesquiterpenes with the expected renal cancer cell selectivity. The most bioactive compound possessed a $\mathrm{GI}_{50}$ of $28 \mathrm{nM}$ in A498 renal cancer cells and demonstrated excellent selectivity. ${ }^{17}$ However, we suspected that a plant would be unlikely to biosynthesize halogenated molecules, and indeed these compounds were soon discovered to be artifacts of isolation that employed outdated chloroform as an eluant for silica gel chromatography. A second isolation procedure yielded only two sesquiterpenes without halogens, named englerins A (1) and B (2). Englerin A reproduced the selectivity of the parent extract and was extremely potent (e.g., an $\mathrm{A}_{498} \mathrm{GI}_{50}$ value of $10 \mathrm{nM}$ ), while englerin B showed no significant cell growth inhibition. The planar structures of the sesquiterpenes were readily established by 2D-NMR techniques, while NOE experiments determined the relative configuration of the seven contiguous stereocenters (Figure 1). It was not possible to determine the absolute configuration of the core carbon skeleton by NMR techniques. In the same work, we prepared the acetate of englerin B (3), obtaining a compound with much weaker potency than englerin A (1350 $\mathrm{nM})$, but with the same renal selectivity profile. ${ }^{5}$ The core sesquiterpene scaffold was a rare epoxy-guaiane skeleton, previously known from very few plants, including Phyllanthus oxyphyllus. ${ }^{18,19}$

With approximately $66 \mathrm{mg}$ of purified englerin A (1) in hand, we considered how to obtain more material. The Letter of Collection ${ }^{20,21}$ with Tanzania had lapsed at that time; thus an updated agreement was negotiated with the Institute of Traditional Medicine in Dar es Salaam. This permitted a large-scale re-collection effort in late 2009 (7 kg of stem bark, 1 $\mathrm{kg}$ roots) from the original location in Iringa Province. Reisolation at NCI Frederick by Rhone Akee and colleagues in 2010 provided $6.8 \mathrm{~g}$ of englerin A of $97 \%$ purity; this sample was sufficient for extensive preclinical work.

\section{Total Synthesis.}

After our initial report of englerin A (1) and its biological activity in January 2009, many total synthesis groups initiated efforts to prepare this target. By October of that year, the Christmann group reported the synthesis of the enantiomeric (+)-englerin A from trans,cisnepetalactone, in 15 steps and $10.9 \%$ overall yield. This established the absolute configuration of the natural product as $1 R, 3 \mathrm{a} R, 4 S, 5 \mathrm{R}, 7 R, 8 S, 8 \mathrm{a} R^{22}$ The (+)-enantiomer was later found to be inactive at $1 \mu \mathrm{M}$ in $\mathrm{A} 498$ cells, while the $\mathrm{IC}_{50}$ of the synthetic (-)enantiomer was $45 \mathrm{nM} .^{23}$ Synthesis of the natural (-)-enantiomer of englerin A, which required synthesis of the unnatural (-)-nepetalactone, was reported by the same group in $2011 .^{23}$

Mere months after the initial Christmann report, the groups of Echavarren ${ }^{24}$ and $\mathrm{Ma}^{25}$ published back-to-back papers using very similar gold-catalyzed domino reactions to synthesize (-)-englerin A (1), with the Echavarren group starting with geraniol (18 steps, $7 \%$ yield) and the Ma group starting with citronellal (15 steps, $8.1 \%$ yield). No biological activity was reported for the final products at the time; however, the optical rotations and spectroscopic data matched those for the natural product. 
Soon after, the Nicoloau/Chen group in Singapore reported a racemic synthesis of englerins A and B and englerin B acetate with biological data for all three compounds in five cancer cell lines. The overall yield for racemic englerin A (1), achieved in 17 steps, was only $2.9 \%$. The racemates were less active than the natural products, as would be predicted, but showed the expected selectivity profiles. ${ }^{26}$ The Theodorakis group followed this with a formal synthesis of englerin A via a [4+3] cycloaddition reaction. ${ }^{27}$

Using a different approach, the Chain group reported a total synthesis of englerin A (1) in just eight steps and $20 \%$ overall yield in $2011 .^{28}$ The scheme combined a substituted 3furanone and 5-methylcyclopentenecarboxaldehyde, with the furanone contributing the oxygen bridge, the bridgehead methyl, and isopropyl groups directly to the tricyclic core and with the aldehyde completing the seven-membered ring. To date, this is the most step- and yield-efficient synthesis of the natural product.

In 2012, Parker described a markedly different approach to the englerin skeleton, using a relay ring-closing metathesis followed by transannular etherification. ${ }^{29} \mathrm{~A} 10$-step sequence yielded an advanced intermediate, which had been previously converted to englerin $\mathrm{A}$, in $6.8 \%$ yield. Cook, using a reductive Heck approach, also achieved a formal synthesis of englerin $\mathrm{A}$ in 2012. ${ }^{30}$

Hatakeyama's group published a novel total synthesis of englerin A (1) that relied on the same carbon skeleton disconnections as Christmann's original synthesis, but which used very different starting materials and chemistry. The key step was cyclization of the fivemembered ring from a chiral epoxynitrile precursor under basic conditions. ${ }^{31}$ While requiring 24 steps, the overall yield was reported as $14 \%$.

A further [4+3] strategy by the Sun and Lin groups was published in 2012 and 2013. A formal total synthesis of englerin A (1) was achieved; however, only (+)-englerin A was prepared. ${ }^{32,33}$ Metz's group reported an efficient total synthesis (12 steps, $16 \%$ yield) in which photocitral A as a starting material was coupled by a Reformatsky reaction to a bromoester; the desired hydroazulene skeleton was then available by ring-closing metathesis (RCM) ${ }^{34}$ Less than a year later, Shen's group reported a similar synthesis, which also started with photocitral; RCM closed the hydroazulene ring, but at a position different from that in the Metz synthesis. ${ }^{35}$

The Anada/Hashimoto group at Hokkaido University reported a unique total synthesis of (-)-englerin A (1) based on carbonyl ylide technology to form the bicyclic ether moiety. ${ }^{36}$ While not particularly step- or yield-efficient ( 25 steps, $5.2 \%$ yield), this approach may provide entry to a particular class of analogues. A [3+2] cycloaddition was used by Iwasawa's group to prepare racemic englerin A with good yield (16.2\%) and in only 14 steps. ${ }^{37}$ The authors had previously reported enantioselective synthesis of the first intermediate in the pathway, which should lead to an asymmetric synthesis of (-)-englerin A in due course. ${ }^{38}$

Very recently, López and Mascareñas and co-workers reported a concise synthesis of (-)englerin A (1), with the key step a platinum-catalyzed [4+3] cycloaddition of an allenediene, providing the trans-fused guaiane skeleton. ${ }^{39}$ The approach was precedented by work of 
Oonishi and Sato, who utilized rhodium catalysis of allenyne precursors to construct the guaiane skeleton with the ether bridge included; however, this intermediate has not yet been converted to an englerin. ${ }^{40}$

Several reviews have summarized synthetic approaches to englerin A (1). In 2010, Willot and Christmann commented on the Echavarren and Ma syntheses. ${ }^{41}$ Chain surveyed work to date in $2011^{42}$ and later published a detailed informal recounting of his own synthesis. ${ }^{43}$ In 2012, Chen and colleagues reviewed the burgeoning field of englerin syntheses. ${ }^{44} \mathrm{~A}$ summary of the varying approaches is represented in Chart 2, with yields and step counts tabulated in Table 1. It is striking that the carbon skeleton has been constructed in so many distinct ways. Each approach has the potential to provide a different spectrum of analogues.

\section{ENGLERIN ANALOGUES}

For any drug development candidate, it is useful to develop structure-activity relationships to aid in target identification, to simplify complex structures, to improve pharmaceutical properties, and to increase potency and selectivity. While englerin A (1) is almost entirely "Lipinski compliant" (i.e., molecular weight $442 \mathrm{Da}$, clogP 5.21, 6 H-bond acceptors, and 1 H-bond donor), ${ }^{45}$ the ester functionalities might be expected to be liabilities with respect to esterase activity, and the cinnamate double bond might be considered a Michael acceptor. Thus, several groups have explored the biological properties of englerin A analogues. The most common biological assay has been the cell growth inhibition of A498 kidney cancer cells with a $48 \mathrm{~h}$ test compound exposure. This cell line, one of the most sensitive to englerin A in the NCI 60 screen, makes it possible to explore large ranges of potency with analogues. It should be pointed out at this juncture that increasing potency has never been a major goal of englerin modification, since the compound is already a highly potent inhibitor of cancer cell growth. Rather, the focus has been on preparing tool compounds to identify targets, simplify structure, and improve pharmaceutical properties. The discussion that follows is organized on the basis of structural themes rather than chronological appearance of analogues.

\section{Radical Reductions of the Core.}

Xie's group reported the synthesis of racemic 4-demethylenglerin A (4). However, the only bioassay data reported were for the kidney cancer cell line ACHN, which possesses low sensitivity to 1 . In any case, activity was not seen at $1 \mu \mathrm{M} .{ }^{46}$ Two simplified analogues having only a bare epoxyguaiane skeleton and a single hydroxy group were prepared by Ito's group, but no biological activity was reported. ${ }^{47}$ Theodorakis's group synthesized analogues lacking the five-membered ring of the englerins ( $\mathbf{5}$ and $\mathbf{6}$ ) but having cinnamate and glycolate esters with the correct stereochemistry; however, these compounds had no effect on the growth of A498 cells at concentrations up to $1 \mu \mathrm{M} .{ }^{48}$ Several other single ring analogues (7-11) in this study were tested in CEM leukemia cells, where they were growth inhibitory at concentrations from 0.1 to $0.4 \mu \mathrm{M}$. These effects were attributed to exocyclic enone functionalities, which likely were acting through electrophilic attack on proteins. ${ }^{48}$ 


\section{Ester Modifications.}

Initial bioactivity data on englerin B (2), in which the glycolate ester is absent, indicated that some functionality was required at this position. In our initial report, we showed that englerin B was essentially inactive, and englerin B acetate (3) was much weaker than englerin A (400-fold in the paper, $\sim 135$-fold based on later unpublished NCI 60 data). ${ }^{5}$ Nicolaou et al. confirmed these differences in potency, albeit with racemic material. ${ }^{26}$ Maier also confirmed the importance of the C-9 position with the synthesis of (-)-9-deoxyenglerin A (12) and reported it to be 1000-fold weaker than englerin A in A498 cells. ${ }^{49}$

Extensive modifications of the cinnamate ester have been reported. We isolated chlorinated analogues as noted above, and $2^{\prime}$-chloroenglerin A (13) was selective for and potently active against kidney cancer cells, with a $\mathrm{GI}_{50}$ value of $28 \mathrm{nM}$ in A498 cells. The other dichloro and hydroxychloro analogues were less active. ${ }^{17}$ Some simple aromatic substitutions on the cinnamate retained potency (14 and 15), ${ }^{50}$ while compounds with more extensive substitution (16-20) had markedly reduced potency. ${ }^{23}$ The ortho-disubstituted 21 was potent, however, hinting that ortho-substitution is tolerated. ${ }^{23}$ Strikingly, the cyclohexyl analogue 22 was equipotent with englerin $\mathrm{A}^{23}$

Modification at the cinnamate double bond also has provided active compounds. The $3^{\prime}-\mathrm{Me}$ compound (23) was highly active, while the Me-2' compound (24) was inactive. ${ }^{23}$ The cyclopropyl isostere (25) was potently active, ${ }^{50}$ and the $\beta$-naphthoate ester (26) was also potent. ${ }^{23}$ Replacement of cinnamate with substituted and unsubstituted benzoates yielded inactive (27 and $\mathbf{2 8}$ ) or weakly active ( 29 and $\mathbf{3 0}$ ) compounds, ${ }^{23,50}$ although the $3^{\prime}, 4^{\prime}$ dichlorobenzoate analogue (31) was moderately potent in A498 cells $\left(\mathrm{IC}_{50} 280 \mathrm{nM}\right){ }^{23}$ The 2-pyridinylcarboxylate ester (32) was inactive. ${ }^{23}$ Small unsaturated esters (33-36) were inactive. $^{23,50}$

\section{Subtle Core Modifications.}

As noted above, removal of the five-membered ring and other radical trimming of the englerin A (1) structure resulted in loss of activity. More subtle changes, however, have provided a great deal of insight into requirements for renal cancer specific cell growth inhibition. Christmann's group, for example, observed a rapid loss of activity when the 7-iPr group was reduced to ethyl $\left(37, \mathrm{IC}_{50} 950 \mathrm{nM}\right)$ and then methyl $(\mathbf{3 8}, 4.6 \mu \mathrm{M}) .{ }^{23}$

Echavarren's group prepared novel modifications of the core englerin skeleton involving either a cis-ring junction or a 4,5-unsaturation. ${ }^{51}$ The latter modification led to potent analogues with cyclopropyl, cyclohexyl, or phenyl substitution at C-7 (39-41), indicating that the $\mathrm{C}-7$ position may be tolerant of further modification, at least in this series. ${ }^{51}$ Another unusual modification involved esterification with cinnamate at a C-4 hydroxy group in two compounds (42 and $\mathbf{4 3}$ ), but these compounds were inactive. ${ }^{51}$

One unique and important core modification was the synthesis of $\mathbf{4 4}$, in which the C-9 ester is reversed. ${ }^{50}$ This compound was potent $\left(\mathrm{IC}_{50} 48 \mathrm{nM}\right.$ in A498 cells), while the free acid $\mathbf{4 5}$ and methylene insertion $\mathbf{4 6}$ were inactive. ${ }^{50}$ This series deserves further exploration. 
Equally important is $\mathbf{4 7}$, where the ester was replaced with an amide to reduce the liability for hydrolysis. ${ }^{52} \mathrm{~A}$ small series of compounds based on this motif were prepared, and while they had modest cell growth inhibitory activity, compound $\mathbf{4 7}$ was orally bioavailable in mice with a substantially longer half-life than 1 injected intraperitoneally. ${ }^{52}$

\section{Scaffold Hopping.}

Andrus's group published the synthesis of three analogues based on borneol and fenchone, with cinnamate and glycolate esters appended. The most active compound (48) was extremely weak, with an $\mathrm{IC}_{50}$ value of $35 \mu \mathrm{M}$ in A498 cells. ${ }^{53}$ The Schneider group utilized englerin A (1) as a template for de novo design of compounds active at TRPC4/5 channels and produced a series of six compounds, some of which (49-52) inhibited TRPM8 channels at low micromolar concentrations. ${ }^{54}$ The compounds were inactive when tested in the NCI 60 screen, however.

Using NCI 60 data, our group identified the purified diterpene natural product tonantzitlolone (53) as a compound with a potentially similar mechanism. Although its $\mathrm{GI}_{50}$ value in A498 cells was $42 \mathrm{nM}$, somewhat weaker than 1, its Pearson correlation coefficient to englerin $\mathrm{A}$ at the $\mathrm{GI}_{50}$ level of response is $0.91 .^{55}$

\section{Tool Compounds.}

The biological study of the englerins now benefits from a wealth of information regarding the structural modifications that are tolerated in biologically active synthetic analogues, as shown in the previous subsection. Moreover, the variety of synthetic approaches that have been developed to date afford the opportunity to generate tool compounds by modification of the natural product at nearly any position. Currently, several distinct mechanisms of action relevant to the activity of the natural product against renal cancer, Ewing's sarcoma, and other sensitive cell lines have been described, including pathways relevant to glucose metabolism, to calcium transport, and others. Pursuant to these mechanisms and pathways, individual cellular biomole-cules and structures have been implicated as possible direct or indirect binding targets of the natural product, including protein kinase $\mathrm{C}$ theta $(\mathrm{PKC} \theta)$, heat shock factor 1 (HSF1), TRPC4/TRPC5 calcium ion channels (tetrameric complexes composed of four individual subunits), L-type calcium channels, and transcription factors.

In an effort to support studies that might validate one of these mechanisms, several groups have modified the natural product to include affinity labels for the noncovalent or covalent modification of cellular targets. Christmann and co-workers have prepared analogues containing photoaffinity labels and alkyne groups for click chemistry. They have reported analogues (Chart 7) containing a modified benzoyl residue in place of the cinnamate function at C-6 containing a diazene unit (54), an analogue containing a clickable alkyne function at the C-6 ester (55), analogues that append a clickable alkyne function at or in place of the C-9 glycolate unit (56-60), and one analogue that combines both a clickable handle and a photoaffiinity label (61). ${ }^{56}$ The Chain group has prepared several englerin analogues in which the $\mathrm{C}-7$ isopropyl group has been modified to include side chains with terminal hydroxy groups that serve as a label attachment point. The linkers developed include a three-carbon tether (62), a 10-carbon tether (63), and a polyethylene (PEG)-based 
tether (not shown), which have varying degrees of biological activity and aqueous solubility (Chart 8 and Supporting Information).

The clinical development of the englerins will require several LC-MS-based assays that are reliant upon conveniently available isotopically labeled natural product analogues in which the labels are incorporated at nonhydrolyzable points. To that end, Chain and co-workers (Supporting Information) have produced monodeuterated and trideuterated analogues of the natural product that required no modification of the synthetic route. The labels were incorporated as a $d_{3}$-C-9/C-8 by base exchange $(\mathbf{6 4})$, as a $d_{3}$-C-10 methyl group by preparation of $d_{3}$-furanone starting material (65), or as a $d$-C-9-methine (66). Attempts to incorporate tritium by these methods have been unsuccessful so far.

\section{MECHANISM OF ACTION STUDIES}

From the start, the question of mechanism of action was raised for englerin A (1). The pattern of selectivity in the NCI 60 screen did not match that of any standard anticancer agent, nor did it match those of compounds with known mechanisms of action. This meant that careful observation of cellular effects in sensitive cancer cell lines was required to generate mechanistic hypotheses.

\section{Empirical Studies.}

Heston et al. conducted a metabolomics study in A498 cells. In a meeting abstract, they identified alterations in carnitine metabolism as the most sensitive effect of englerin A (1). ${ }^{57}$ Flow cytometry showed that A498 cells were delayed in progression through the $\mathrm{S}$ phase. ${ }^{57}$

Ramos's group reported that 1 reduced the viability of renal cancer cell lines (UO-31 and A498) at mid-nanomolar concentrations (140 and $53 \mathrm{nM}$, respectively), but had no effect on normal immortalized kidney cells (HEK-293), renal proximal tubule cells (RPTC), or glioblastoma cells (SF-295) up to $10 \mu \mathrm{M} .{ }^{58}$ These values were measured using a tetrazolium (XTT) end point, which is sensitive to cellular metabolic activity. ${ }^{1}$ Note that the primary NCI 60 screen has utilized sulforhodamine B (SRB) as its end point. ${ }^{2}$ This is a stain for total cellular protein that might be expected to yield somewhat different results from XTT, depending on a compound's mechanism of action. Ramos's group also excluded apoptosis and autophagy as cell death mechanisms for englerin A, while finding elevated reactive oxygen species in englerin-treated A498 cells, but not in treated SF-295 glioblastoma cells. ${ }^{58} \mathrm{An}$ increase in intracellular calcium concentration was found after englerin exposure, and this was interpreted as evidence for a necrotic mechanism. ${ }^{58}$

Work by Batova et al. with A498 cells reported apoptotic mechanisms, which occurred at very high concentrations of $\mathbf{1}$, in a caspase-independent manner, and required at least $24 \mathrm{~h}$ of test compound exposure. This behavior is in contrast to typical pathways of apoptosis, indicating that upstream events might be involved. The authors proposed that metabolic stress might induce autophagy, and englerin A (1) treatment was shown to induce autolysosomes in a manner similar to that of rapamycin. ${ }^{59}$ Further experiments showed that englerin treatment led to conversion of the molecular marker LC3B-I to LC3B-II. Also, supplementation of cells with nonessential amino acids reduced englerin A-stimulated 
autophagic vesicles. The authors concluded, however, that autophagy did not play a direct role in cell death due to englerin A, but represented a cell defense mechanism that eventually failed, leading to apoptotic cell death and necrosis. ${ }^{59}$ AKT and ERK phosphorylation was reduced by $\mathbf{1}$; however, AMPK was not activated by $\mathbf{1}$. The compound arrested cells in G2 by blocking the G2/M transition. ${ }^{59}$

Haque and Banerjee, working with the renal cancer cell lines CAKI-1 and 786-0 and focusing on potential mechanisms for blocking metastasis, proposed a different mechanism for 1. Englerin A reduced migration and invasion by these cell lines at noncytotoxic concentrations, inhibiting TGF- $\beta 1$-induced epithelial-mesenchymal transition. ${ }^{60}$ Mesenchymal markers (Twist protein, CD44, ABCG2, ALDH1, and spheroid formation) were upregulated, while epithelial markers were downregulated. Englerin A also inhibited TGF $\beta 1$-induced angiogenesis. ${ }^{60}$

\section{Protein Kinase C $\theta$.}

Members of the NCI Urologic Oncology Branch began investigation of the mechanism of action of englerin A (1) by testing the compound in a panel of isogenic cell pairs in which a genetically defined kidney cancer (RCC) cell line (clear cell RCC: 786-0; hereditary leiomyomatosis RCC: UOK262; and Birt-Hogg-Dubé syndrome: UOK257) was paired with a "restored" cell line in which the lesion had been corrected. All three original cell lines were sensitive to 1 at concentrations of 35-50 nM, while the restored cell lines were all insensitive at $>10 \mu \mathrm{M} .{ }^{61}$ Notably, all of the sensitive cell lines were also sensitive to 2deoxyglucose, indicating that glucose dependence might play a role in the mechanism of action. A prediction based on the structure of $\mathbf{1}$, using the Metadrug platform, suggested that protein kinase $\mathrm{C}(\mathrm{PKC})$ might be involved, since half of the 15 potential targets were $\mathrm{PKC}$ isoforms. Thus, experimental validation of this prediction was undertaken. A pan-PKC assay with whole cell extracts found that englerin A stimulated pan-PKC phosphorylation activity. RNA interference experiments with reagents for different isoforms, in live cells, found that only PKC $\theta$ RNAi blocked $786-0$ cell viability. ${ }^{61}$ This selectivity was confirmed with further in vitro studies in which phosphorylation of IRS1 on S1101, a known substrate of PKC $\theta$, was enhanced by englerin A in a dose-dependent fashion. Furthermore, englerin A was found to displace a fluorescent phorbol ester, $\mathrm{SAPD}$, from $\operatorname{PKC} \theta \cdot{ }^{61}$ Other unpublished experiments have so far failed to confirm direct binding properties of englerin A to PKC $\theta$ isolated protein domains.

Further exploration of the prediction of an effect on glucose metabolism found that englerin A (1)-induced inhibitory phosphorylation of IRS1 decreased downstream activating phosphorylation of AKT and GSK3 $\beta$. This result is consistent with induction of an insulinresistant phenotype. Indeed, 1 reduced glucose uptake in 786-0 cells and decreased cellular ATP levels. Likewise, addition of dominant negative AKT constructs enhanced englerin A cytotoxicity, while a constitutively active AKT construct protected cells from englerin A. ${ }^{61}$

A second arm of PKC $\theta$-related effects in 786-0 cells was determined to be induction of heat shock factor 1 (HSF1). In fact, experiments using HEK293 cells, which are insensitive to 1 and contain little PKC $\theta$ and modest levels of HSF1, showed that addition of both $\operatorname{PKC} \theta$ and HSF1 constructs is required to generate a cell that is sensitive to $\mathbf{1}$. The ultimate conclusion 
was that, at least in 786-0 cells, englerin A induces glucose addiction through HSF1, while simultaneously starving the cell of glucose through inhibition of transport. ${ }^{61}$ Note, however, that the Waldmann group reported a lack of expression of PKC $\theta$ in A498 cells, ${ }^{62}$ although the NCI group has detected it in the same cells, despite both groups using well-validated cell lines.

\section{Transient Receptor Potential Canonical 4/5.}

The Waldmann group attempted to utilize affinity methods to isolate protein targets; however, these were unsuccessful, indicating either a low abundance protein or a membrane protein. G-Protein coupled receptors (GPCRs) and ion channels are such potential targets. Random screening revealed only weak inhibition in a panel of GPCR and ion channel assays; however a report of correlation between transient receptor potential canonical channel 4 (TRPC4) led the investigators to explore this target in functional studies. Indeed, the activities of TRPC4 and its close relative TRPC5 were stimulated by englerin A (1), inducing calcium influx. ${ }^{62}$ The effect on calcium was congruent with Ramos's previous reports and with work later reported at NCI. ${ }^{58,63}$ The effect was blocked by the TRPC4 inhibitor ML204, ${ }^{64}$ and cells were rescued from englerin A cytotoxicity by EGTA, a cellimpermeable calcium chelator. ${ }^{62}$ GPCR-stimulated activation of TRPC $4 / 5$ channels was ruled out by blockade of GPCR signaling by a stable guanosine diphosphate analogue. ${ }^{62}$

Workers at Novartis came to the same conclusion via extensive cell line profiling and bioinformatics analysis, in which they correlated TRPC4 expression with englerin A (1) sensitivity in 524 cell lines. The Waldmann group reported that transfection of TRPC4 into HEK293T cells rendered the otherwise insensitive cells sensitive to englerin A. ${ }^{65}$ On the basis of their inability to detect PKC $\theta$ in A498 cells or the sensitive Ewing's sarcoma cell line A673, this group concluded that $\mathrm{PKC} \theta$ could not be the target of englerin $\mathrm{A}$, but that TRPC4/5 agonism was the relevant effect. ${ }^{65} \mathrm{~A}$ recent report from Beech's group found that englerin A cytotoxicity was mediated by influx of sodium, rather than of calcium, as had been previously proposed, and that both TRPC4 and TRPC1 must be part of the ion channel complex for cytotoxicity. ${ }^{66}$

\section{Other Targets?}

Another ion channel recently identified by a chemoinformatic approach as a potential site for englerin $A$ is the L-type calcium channel $\mathrm{Ca}_{\mathrm{v}} 1.2$. The potency of englerin $\mathrm{A}(\mathbf{1})$ in this biological system was only $6 \mu \mathrm{M}$, indicating that while it may be a useful probe of the channel, it is unlikely to play a major role in the effect of englerin A on kidney cancer cells. 67

\section{PRECLINICAL STUDIES}

Preclinical studies at the NCI began soon after the completion of isolation and structure elucidation of englerin A (1). A dose for intraperitoneal injection in mice was established at $5 \mathrm{mg} / \mathrm{kg}$, since a dose of $10 \mathrm{mg} / \mathrm{kg}$ was lethal to a single untumored mouse and $5 \mathrm{mg} / \mathrm{kg}$ to a single mouse was not. The vehicle used was DMSO. A xenograft experiment with the renal cancer cell line RXF 393 and doses of 5, 2.5, and $1.25 \mathrm{mg} / \mathrm{kg}$ ( $n=8$ per group) given every 
fourth day for five treatments showed no efficacy; however, the mice tolerated all of the doses, confirming the tolerated dose.

Xenografts with another renal cancer cell line, 786-0, were more successful. Administering $5 \mathrm{mg} / \mathrm{kg}$ daily of 1 for 14 consecutive days resulted in marked reduction in tumor growth in two separate experiments. As noted above in the discussion of mechanism of action, the phosphorylation of downstream targets of $\operatorname{PKC} \theta$, IRS1, and GSK3 $\beta$ was modulated in tumors from this experiment. ${ }^{61}$ A xenograft of PC-3 prostate cancer cells using the same dose regimen also showed efficacy, though less than the renal xenograft. While PC-3 cells were not sensitive in the NCI 60 experiment, varied conditions of cell culture showed different levels of cell growth inhibition of this cell line by englerin A. ${ }^{61}$

At this point, it seemed worthwhile to develop legitimate pharmaceutical formulations for englerin A (1). At NCI-Frederick, Sima Hayavi developed both parenteral and oral formulations. The parenteral formulation utilized cyclodextrin with several polyoxyethylene glycols to yield a clear solution at $5.7 \mathrm{mg} / \mathrm{mL}$; this was shown to be stable at refrigerator temperatures for 1 week. A simple oral formulation in Labrasol at $20 \mathrm{mg} / \mathrm{mL}$ was also developed and shown to be stable. ${ }^{52}$

We instituted initial pharmacokinetic experiments at NCI with a sensitive HPLC-MS assay for englerin A (1) in body fluids developed by Cody Peer and colleagues. ${ }^{52}$ In mice, a maximum tolerated dose of $10 \mathrm{mg} / \mathrm{kg}$ i.p. was determined with the new formulation; however, on intravenous administration, doses decreasing to $0.1 \mathrm{mg} / \mathrm{kg}$ were immediately lethal. ${ }^{52}$ The extreme intravenous lethality is consistent with data reported by the Novartis group, while the Novartis workers were unable to deliver $\mathbf{1}$ by the intraperitoneal route, even at doses as low as $1 \mathrm{mg} / \mathrm{kg}$. Note that a Cremophor emulsion was used by Novartis. ${ }^{65}$ In the event, pharmacokinetic measurements at NCI with intraperitoneal administration showed a short half-life of $\sim 30 \mathrm{~min}$, with levels of $15-25 \mathrm{ng} / \mathrm{mL}$ in plasma. In contrast, oral administration of englerin A up to $100 \mathrm{mg} / \mathrm{kg}$ yielded no detectable englerin A in plasma and no overt toxicity.

Further xenograft studies of 1 were conducted at NCI with UOK262 renal cancer cells and A673 Ewing's sarcoma cells and the new parenteral formulation given i.p.; however, there was a lack of efficacy in each case. Although this led to suspicions that the new vehicle was somehow inadequate, a recent unpublished xenograft study by Haque and Banerjee has shown activity with the new vehicle and 786-0 renal cancer cells. Thus, the problem is more likely to be poor drug exposure in the tumor due to a short half-life.

\section{Activity in Other Cancers.}

In a high-throughput reporter-gene screen at NCI for inhibitors of the Ewing's sarcoma transcription factor EWS-FLI1, 68 the same root bark and stem bark extracts of $P$. engleri that yielded englerin A (1) were identified as active. ${ }^{63}$ The pure compound englerin A (1) was readily identified as potently active in the screen. Further mechanistic work by Woldemichael and Grohar ruled out $\operatorname{PKC} \theta$ as a target in Ewing's sarcoma cells, pointing instead to inhibition of the EWS-FLI1 transcription factor binding to DNA via a reduction of phosphorylation of the transcription factor. Cytosolic calcium levels were elevated, leading 
to a decrease in levels of $\mathrm{PKC} \beta 1$, which is calcium-sensitive, in contrast to $\operatorname{PKC} \theta{ }^{63} \mathrm{~A}$ broader sarcoma cellular screen at NCI showed that 10/20 Ewing's sarcoma cell lines were sensitive, while most other sarcomas were resistant, a result that paralleled the NCI 60 data (Table S1, Supporting Information). ${ }^{69}$ The typology of Ewing's sarcoma cell lines as distinguished by Khan et al. ${ }^{70}$ did not correlate with englerin A sensitivity, however.

Englerin A has been reported to be active against a few cells from other tumor types, including bladder cancer and breast cancer (i.e., HS 578T and BT-549 in the NCI 60); however no publications have yet appeared on these topics.

\section{Combination Studies.}

In collaboration with the National Center for Advancing Translational Sciences (NCATS, $\mathrm{NIH}$ ), an NCI-funded project examined combinations of a wide variety of drug candidates or drugs in cancer cellular systems. ${ }^{71}$ Englerin A (1) scored well in UOK121 kidney cancer cells when combined with sepantronium bromide, a putative survivin inhibitor, and in TC71 Ewing's sarcoma cells when combined with ABT-263, a bcl-2 inhibitor (unpublished data, Figure 1, Table S2, Supporting Information). Recently, Beech et al. suggested that $\mathrm{Na}^{+} / \mathrm{K}^{+}$ ATPase inhibitors such as ouabain may synergize with englerin A in the proper context. ${ }^{66}$ In the NCATS study mentioned above, a modest amount of synergy was seen with proscillaridin, but not with ouabain in Ewing's sarcoma cells. Such synergies justify in vivo combination studies to guide future clinical therapy and may inform mechanistic studies of all compounds involved.

\section{Other Potential Biological Activities.}

Due to observation of inhibition of glucose transporter activity and abrupt decreases of blood glucose in tumored mice, ${ }^{55}$ we have proposed that englerin A (1) or its analogues might be useful in diabetes and other disorders of glucose metabolism. ${ }^{72}$ At this time, no further studies have been conducted to justify this proposal.

Similarly, the discovery of englerin A (1) effects on PKC $\theta$ led us to propose that $\mathbf{1}$ might have activity in breaking HIV latency in T lymphocytes. ${ }^{73}$ The PKC ligands prostratin and bryostatin 1 are well-known standards in this area of research. ${ }^{74-76}$ Different isoforms of PKC are thought to play different roles in viral latency. ${ }^{77}$ Studies to examine this idea with $\mathbf{1}$ are in progress.

\section{Patents.}

The NCI filed a composition of matter and use in cancer treatment patent on englerins in 2008 which issued in the U.S. in $2015 .{ }^{78}$ European patents covering 14 European countries have also issued for the same matter, ${ }^{79}$ as well as in Japan ${ }^{80}$ and Australia. ${ }^{81}$ The Christmann group filed on a series of analogues of englerin A in $2010,{ }^{56}$ while the Echavarren group filed on methods of englerin synthesis, along with several analogues, in $2011 .^{82}$

On the basis of effects of englerin A (1) on T lymphocytes, the NCI filed a patent on its use for breaking viral latency in retroviral infection. ${ }^{73}$ Following up on the inhibitory effects 
observed with glucose transporters, a patent was filed on potential use in type 2 diabetes. $^{72}$ Most recently, patent applications for the Chain aza-analogues ${ }^{83}$ and the Echavarren analogues ${ }^{84}$ have been filed jointly between the $\mathrm{NCI}$ and their respective institutions.

\section{DISCUSSION}

\section{Structure-Activity Relationships.}

Over 100 analogues of englerin A (1) have appeared in the chemical literature to date, and approximately 25 of them have $\mathrm{IC}_{50}$ values less than $200 \mathrm{nM}$ against A498 cells. The most critical position on the molecule is the glycolate moiety. Removal of the glycolate completely ablates activity in cancer cells. Replacement of the glycolate with other small esters is possible, with their ability to accept hydrogen bonds seeming to be critical to success. Reversal of the ester group has been demonstrated to maintain activity in only one compound (44) of three prepared, but may be worthy of further exploration. ${ }^{50}$ Conversion to a glycolamide shows some promise, but the low intrinsic activity this series has shown so far is puzzling. ${ }^{52}$

Another sensitive and important site is the bridgehead isopropyl group. Replacement with ethyl or methyl at this position leads to rapid loss of potency (e.g., $\mathbf{3 7}$ and 38), ${ }^{23}$ while substitution of cyclopropyl, phenyl. or cyclohexyl is tolerated (39-41). ${ }^{51}$

The five-membered ring is relatively tolerant of a variety of modifications, indicating that it is not sterically constrained. The cis-ring junction is tolerated, as is unsaturation between C-4and C-5. ${ }^{51}$

The cinnamate moiety is least affected by structural alterations. Note that the cyclohexyl (22) and $\beta$-naphthoate (26) analogues both possess good activity. This indicates that electronic effects on activity are minimal and that lipophilic substituents in general are permitted. However, p-substituted cinnamates have generally shown poor potency (exception: p-F 15), and englerins with small ester groups at C-6 have generally been inactive.

These observations are summarized in Figure 2.

\section{PKC versus TRPC4.}

The discovery of the potent activity of englerin A (1) at two distinct targets, PKC $\theta$ and TRPC4/5, in which the compound is an agonist in both systems, raises important questions. Neither target has had a strong connection to cancer pathology.

$\operatorname{PKC} \theta$ was originally discovered in T-lymphocytes, in which it is essential for T-cell activation and survival. ${ }^{85}$ It was also found in muscle tissue, brain, and platelets. ${ }^{85} \mathrm{It}$ is a member of the novel PKC subgroup along with $\mathrm{PKC} \delta,-\varepsilon$, and $-\eta$, which are responsive to phorbol esters and diacylglycerol but, unlike the classical subgroup (PKC- $a,-\beta$, and - $\mathcal{\text { ) }}$, are independent of calcium. ${ }^{86}$

PKC $\theta$ is overexpressed in gastrointestinal stromal tumors, ${ }^{87}$ promotes mammary tumorigenesis by a novel epigenetic mechanism involving c-Rel, ${ }^{88}$ and has been proposed as 
a target for T cell leukemias. ${ }^{89}$ Therapeutic intervention for these conditions would require inhibition of $\mathrm{PKC} \theta$ function. Indeed, inhibition of $\mathrm{PKC} \theta$ has been a target for antiinflammatory indications, with some success in developing inhibitors specific for $\mathrm{PKC} \theta$ over PKC $\delta .^{90}$

TRPC4 is an ion channel, or more properly a protein component of heteromultimeric ion channels. It is found in a variety of human tissues, including the brain, heart, eye, and kidney. ${ }^{91}$ It has been characterized as a calcium-selective channel activated by G-protein coupled receptors and by calcium stores. Knockout mice are fertile and exhibit no obvious signs of dysfunction, indicating that parallel signaling pathways can compensate for TRPC4 function. The diverse nature of TRPC4-containing channels suggests that inhibition or stimulation of a channel in one cell type by a pharmacologic agent such as englerin A (1) may not have the same effect in another cell type. ${ }^{91}$

Investigations into the role of TRPC4 in cancer had been modest until the discovery of englerin A (1). TRPC1 and TRPC4 had been found to play differing roles in LNCaP prostate cancer cells. ${ }^{92}$ In renal cancer cells, TRPC4 was found to control angiogenesis and thrombospondin-1 secretion. ${ }^{93}$ Ovarian cancer cells expressed high levels of TRPC $4 \beta$ and TRPC $4 \gamma$, with nonselective TRPC inhibitors blocking cell proliferation. ${ }^{94}$ Recent reviews have surveyed the current state of affairs of the relationship between TRPC channels and cancer. ${ }^{95,96}$

The evidence for both PKC $\theta$ and TRPC4 as targets for englerin A (1) in kidney cancer cells is strong. In particular, the stimulation of S1101 phosphorylation of purified IRS1 by englerin A with purified $\operatorname{PKC} \theta$ at two different end points argues that one of the two proteins must bind englerin A. ${ }^{61}$ The same effects were seen in 786-0 cells and in 786-0 xenografted tumors. ${ }^{61}$ Similarly, the evidence for TRPC4/5 is undeniable, having been elucidated independently in two different groups using different strategies. ${ }^{62,65}$

Woldemichael et al. found that $\operatorname{PKC} \theta$ is unlikely to be the target in A673 and TC32 Ewing's sarcoma cells, ${ }^{63}$ based on RNAi experiments similar to those done by Sourbier et al. ${ }^{61}$ They observed a sustained increase of cytosolic calcium levels with englerin A (1), similar to that seen in A498 cells by other groups. ${ }^{58,62,65}$ The unique cell biology of Ewing's sarcoma is selectively affected by englerin A through decreased phosphorylation of the chimeric EWSFLI1 transcription factor. ${ }^{63}$

Thus, the question becomes, are the two phenomena (PKC $\theta$ and TRPC4) linked in some way, or are they independent? If they are independent, it should be possible, in principle, to design analogues that are selective for one or the other target. Alternatively, if the phenomena are unique to different types of cancer cells, targeting an englerin A analogue to the susceptible cells through antibody-drug conjugates or nanomaterials might provide a solution. If they are inextricably linked, only a protein-targeted strategy is likely to be successful. 


\section{Analogue Mechanism Studies.}

Few of the analogues mentioned above have been tested in any assay other than cancer cell growth. Thus, at present there is very little evidence to answer the question of whether PKC $\theta$ and TRPC $4 / 5$ stimulation can be separated. The aza-englerin analogue $\mathbf{4 7}$ had no detectable PKC $\theta$ activity at $1 \mu \mathrm{M}$, but was weak in cell growth inhibition. ${ }^{52}$ The diterpene tonantizitlolone (53) has been reported to be inactive at TRPC $4 / 5$ (unpublished), while it is potent for both PKC $a$ and PKC $\theta$ but not selective between them. ${ }^{55}$ In addition, tonantzitlolone and its enantiomer were recently reported to inhibit kinesin binding to microtubules. ${ }^{97}$ Further studies to test englerin analogues against both PKC $\theta$ and TRPC4 targets are in progress.

\section{Conflicting Data.}

Several reports on englerin A (1) and its properties are conflicting on certain points. These are noted here.

At NCI, and in one collaborating laboratory, using both a DMSO vehicle and the recently reported cyclodextrin preparation, we have successfully administered 1 at $5 \mathrm{mg} / \mathrm{kg}$ for 14 consecutive days in multiple mouse studies without serious morbidity. ${ }^{52,61}$ However, the Novartis group was unable to administer 1 to mice by the intraperitoneal route without toxicity. ${ }^{65}$ It is possible that the Cremophor vehicle used by the Novartis group somehow potentiates the toxic effect of $\mathbf{1}$ by this route.

A second point of conflict concerns the Waldmann group's inability to detect PKC $\theta$ in A498 cells, which was a major stimulus in their search for another target. ${ }^{62}$ At the NCI we have detected PKC $\theta$ in our A498 cells. Correspondence with the Waldmann group has not led to any reason to suspect the identification of the cells in either laboratory.

A third point of difficulty is the overall lack of correlation between the presence and protein expression level of PKC $\theta$ and TRPC4 in different cancer cell lines and the sensitivity of the cell lines to englerin A. Clearly many accessory factors may be involved for either target, as seen by our observation that both arms of the PKC $\theta$ mechanism (IRS1 and HSF1) are required for cellular sensitivity ${ }^{61}$ and by the complexity of the TRPC4 multiheteromeric complexes. ${ }^{98}$

\section{The Way Forward to the Clinic.}

To address some of these concerns and to propel further progress in the field, a meeting was organized in October 2016 at NCI-Frederick, with many members of the research groups cited in this review in attendance. A substantial body of new information was presented on work in progress, and this will very likely be published in the coming year, adding to the englerin story.

The key questions that must be answered to achieve clinical success include management of toxicity, preparation of more potent orally bioavailable englerin analogues, and better understanding of the mechanism(s) of action/toxicity and of metabolism, pharmacokinetics, and distribution. It is hoped that structural biology and systems biology can be utilized to 
explain the varied pharmacologic effects that have been observed. The path to clinical use is rarely simple or straightforward, and englerins still have to surmount several barriers to that goal. Nonetheless, the promise of their initial discovery may still prevail.

\title{
Supplementary Material
}

Refer to Web version on PubMed Central for supplementary material.

\section{ACKNOWLEDGMENTS}

\begin{abstract}
This work was supported by the Intramural Research Program of the National Cancer Institute, National Institutes of Health, Department of Health and Human Services (J.A.B.), as well as by grant R01CA163287 from the National Cancer Institute (Z.W., W.J.C.). Some data were acquired at UD on instruments obtained with the assistance of NSF and NIS funding (NSF CHE0421224, CHE1229234, and CHE0840401; NIH P20GM103541, P20GM104316, P30GM110758, S10RR02692, and S10OD016267). We thank G. Schneider for samples of 49-52 for NCI 60 testing, C. Thomas and NCATS for the combination studies using englerin A, R. Akee for large-scale reisolation of englerin A, B. Teicher and D. Evans for sarcoma cell screening, M. Hollingshead for the RXF 393 xenograft, S. Difillipantonio for UOK262 and A673 xenografts, and K. Parker for helpful comments and collaboration.
\end{abstract}

\section{DEDICATION}

Dedicated to Professor Phil Crews, of the University of California, Santa Cruz, for his pioneering work on bioactive natural products, and to the late Professor Zakaria Heriel Mbwambo, who made the initial NCI-supported collection of Phyllanthus engleri.

\section{REFERENCES}

(1). Alley MC; Scudiero DA; Monks A; Hursey ML; Czerwinski MJ; Fine DL; Abbott BJ; Mayo JG; Shoemaker RH; Boyd MR Cancer Res 1988, 48, 589-601. [PubMed: 3335022]

(2). Shoemaker RH Nat. Rev. Cancer 2006, 6, 813-823. [PubMed: 16990858]

(3). Srinivasan R; Ricketts CJ; Sourbier C; Linehan WM Clin. Cancer Res 2015, 21, 10-17. [PubMed: 25564569]

(4). Vira MA; Novakovic KR; Pinto PA; Linehan WM BJU Int 2007, 99, 1223-1229. [PubMed: 17441915]

(5). Ratnayake R; Covell DG; Ransom TT; Gustafson KR; Beutler JA Org. Lett 2009, 11, 57-60. [PubMed: 19061394]

(6). Cantrell CL; Groweiss A; Gustafson KR; Boyd MR Nat. Prod. Lett 1999, 14, 39-46.

(7). Webster GL Ann. Mo. Bot. Gard 1994, 81, 3-32.

(8). Unander DW; Webster GL; Blumberg BS J. Ethnopharmacol 1990, 30, 233-264. [PubMed: 2259214]

(9). Calixto JB; Santos AR; Cechinel FV; Yunes RA Med. Res. Rev 1998, 18, 225-258. [PubMed: 9664291]

(10). Qi W; Hua L; Gao K Chem. Biodiversity 2014, 11, 364-395.

(11). Barton DHR; Page JE; Warnhoff EW J. Chem. Soc 1954, 2715-2719.

(12). Alberman KB; Kipping FB J. Chem. Soc 1951, 2296-2297.

(13). Verdcourt B; Trump EC Common Poisonous Plants of East Africa; Collins: London, 1969.

(14). Breyer-Brandwijk MGQ J. Pharm. Pharmacol 1934, 7, 167-178.

(15). Watt JM; Breyer-Brandwijk MG Bantu Studies 1927, 3, 395-400.

(16). Moshi MJ; Mbwambo ZH; Nondo RSO; Masimba PJ; Kamuhabwa A; Kapingu MC; Thomas P; Richard M Afr. J. Trad. Comp. Alt. Med 2006, 3, 48-58.

(17). Akee RK; Ransom TT; Ratnayake R; McMahon JB; Beutler JA J. Nat. Prod 2012, 75, 459-463. [PubMed: 22280462]

(18). Sutthivaiyakit S; Nakorn NN; Kraus W; Sutthivaiyakit P Tetrahedron 2003, 59, 9991-9995. 
(19). Peng GP; Tian G; Huang XF; Lou FC Phytochemistry 2003, 63, 877-881. [PubMed: 12895533]

(20). Beutler JA; Cragg GM; Newman DJ In Drug Discovery in Africa; Chibale K; Davies-Coleman MT; Masimirembwa C, Eds.; Springer: Berlin, 2012; pp 29-51.

(21). Cragg GM; Katz F; Newman DJ; Rosenthal J Nat. Prod. Rep 2012, 29, 1407-1423. [PubMed: 23037777]

(22). Willot M; Radtke L; Könning D; Fröhlich R; Gessner VH; Strohmann C; Christmann M Angew. Chem., Int. Ed 2009, 48, 9105-9108.

(23). Radtke L; Willot M; Sun H; Ziegler S; Sauerland S; Strohmann C; Frohlich R; Habenberger P; Waldmann H; Christmann M Angew. Chem., Int. Ed 2011, 50, 3998-4002.

(24). Molawai K; Delpont N; Echavarren AM Angew. Chem., Int. Ed 2010, 49, 3517-3519.

(25). Zhou Q; Chen X; Ma D Angew. Chem., Int. Ed 2010, 49, 3513-3515.

(26). Nicolaou KC; Kang Q; Ng SY; Chen DY J. Am. Chem. Soc 2010, 132, 8219-8222. [PubMed: 20496885]

(27). Xu J; Caro-Diaz EJ; Theodorakis EA Org. Lett 2010, 12, 3708-3711. [PubMed: 20669919]

(28). Li Z; Nakashige M; Chain WJ J. Am. Chem. Soc 2011, 133, 6553-6556. [PubMed: 21476574]

(29). Lee J; Parker KA Org. Lett 2012, 14, 2682-2685. [PubMed: 22564056]

(30). Gao P; Cook SP Org. Lett 2012, 14, 3340-3343. [PubMed: 22679931]

(31). Takahashi K; Komine K; Yokoi Y; Ishihara J; Hatakeyama SJ Org. Chem 2012, 77, 7364-7370.

(32). Wang CL; Sun BF; Chen SG; Ding R; Lin GQ; Xu JY; Shang YJ Synlett 2012, 23, 263-266.

(33). Wang J; Chen SG; Sun BF; Lin GQ; Shang YJ Chem. - Eur. J 2013, 19, 2539-2547. [PubMed: 23292997]

(34). Zahel M; Kessberg A; Metz P Angew. Chem., Int. Ed 2013, 52, 5390-5392.

(35). Zhang J; Zheng S; Peng W; Shen Z Tetrahedron Lett 2014, 55, 1339-1341.

(36). Hanari T; Shimada N; Kurosaki Y; Thrimurtulu N; Nambu H; Anada M; Hashimoto S Chem. Eur. J 2015, 21, 11671-11676. [PubMed: 26179743]

(37). Kusama H; Tazawa A; Ishida K; Iwasawa N Chem. - Asian J 2016, 11, 64-67. [PubMed: 26377511]

(38). Ishida K; Kusama H; Iwasawa NJ Am. Chem. Soc 2010, 132, 8842-8843.

(39). Nelson R; Gulias M; Mascarenas JL; Lopez F Angew. Chem., Int. Ed 2016, 55, 14359-15363.

(40). Oonishi Y; Yokoe T; Hosotani A; Sato Y Angew. Chem., Int. Ed 2014, 53, 1135-1139.

(41). Willot M; Christmann M Nat. Chem 2010, 2, 519-520. [PubMed: 20571563]

(42). Chain WJ Synlett 2011, 18, 2605-2608.

(43). Chain WJ In Strategies and Tactics in Organic Synthesis; Harmata M, Ed.; Elsevier: Oxford, 2013; Vol. 9, pp 79-104.

(44). Pouwer RH; Richard JA; Tseng CC; Chen DY Chem. - Asian J 2012, 7, 22-35. [PubMed: 22162365]

(45). Lipinski CA; Lombardo F; Dominy BW; Feeney PJ Adv. Drug Delivery Rev 1997, 23, 3-25.

(46). Dong L; Jiao XZ; Liu XY; Tian CS; Li XY; Yao YY; Xie PJ Asian Nat. Prod. Res 2014, 16, 629-639.

(47). Abe H; Tezuka A; Kobayashi T; Ito H Heterocycles 2014, 88, 651-662.

(48). Xu J; Caro-Diaz EJ; Batova A; Sullivan SD; Theodorakis EA Chem. - Asian J 2012, 7 , 1052-1060. [PubMed: 22415793]

(49). Ushakov DB; Navickas V; Ströbele M; Maichle-Mössmaer C; Sasse F; Maier ME Org. Lett 2011, 13, 2090-2093. [PubMed: 21413694]

(50). Chan KP; Chen DY ChemMedChem 2011, 6, 420-423. [PubMed: 21360817]

(51). López-Suárez L; Bravo F; Riesgo L; Ransom TT; Beutler JA; Echavarren AM ChemMedChem 2016, 11, 1003-1007. [PubMed: 27005578]

(52). Fash DM; Peer CJ; Li Z; Talisman IJ; Hayavi S; Ramos JW; Figg WD; Beutler JA; Chain WJ Bioorg. Med. Chem. Lett 2016, 26, 2641-2644. [PubMed: 27107948]

(53). Acerson MJ; Bingham BS; Allred CA; Andrus MB Tetrahedron Lett 2015, 56, 3277-3280. 
(54). Friedrich L; Rodrigues T; Neuhaus CS; Schneider P; Schneider G Angew. Chem., Int. Ed 2016, 55, 6789-6792.

(55). Sourbier C; Scroggins B; Mannes PZ; Liao PJ; Siems K; Wolf D; Beutler JA; Linehan WM; Neckers L Oncotarget 2015, 6, 29963-29974. [PubMed: 26298773]

(56). Christmann M; Radtke L; Waldmann H; Willot M; Ziegler S; Sun H WIPO Appl 2012/084267, 2012.

(57). Harsch K; Roth J; Koepf B; Wang X; Yin L; Heston WDW AACR Annual Meeting, Orlando, FL, 2011; Abstract 983.

(58). Sulzmaier FJ; Li Z; Nakashige ML; Fash DM; Chain WJ; Ramos JW PLoS One 2012, 7, e48032. [PubMed: 23144724]

(59). Williams RT; Yu AL; Diccianni MB; Theodorakis EA; Batova AJ Exp. Clin. Cancer Res 2013, $32,1-13$.

(60). Haque I; Banerjee S; Beutler JA; Banerjee SK AACR Annual Meeting, Philadelphia, PA, 2015; Abstract 5322.

(61). Sourbier C; Scroggins BT; Ratnayake R; Prince TL; Lee S; Lee JM; Trepel JB; Beutler JA; Linehan WM; Neckers LM Cancer Cell 2013, 23, 228-237. [PubMed: 23352416]

(62). Akbulut Y; Gaunt HJ; Muraki K; Ludlow MJ; Amer MS; Bruns A; Vasudev NS; Radtke L; Willot M; Hahn S; Seitz T; Ziegler S; Christmann M; Beech DJ; Waldmann H Angew. Chem., Int. Ed 2015, 54, 3787-3791.

(63). Caropreso V; Darvishi E; Turbyville TJ; Ratnayake R; Grohar PJ; McMahon JB; Woldemichael GJ Biol. Chem 2016, 291, 10058-10066.

(64). Miller M; Shi J; Zhu Y; Kustov M; Tian JB; Stevens A; Wu M; Xu J; Long S; Yang P; Zholos AV; Salovich JM; Weaver CD; Hopkins CR; Lindsley CW; McManus O; Li M; Zhu MX J. Biol. Chem 2011, 286, 33436-33446. [PubMed: 21795696]

(65). Carson C; Raman P; Tullai J; Xu L; Henault M; Thomas E; Yeola S; Lao J; McPate M; Verkuyl JM; Marsh G; Sarber J; Amaral A; Bailey S; Lubicka D; Pham H; Miranda N; Ding J; Tang HM; Ju H; Tranter P; Ji N; Krastel P; Jain RK; Schumacher AM; Loureiro JJ; George E; Berellini G; Ross NT; Bushell SM; Erdemli G; Solomon JM PLoS One 2015, 10, e0127498. [PubMed: 26098886]

(66). Ludlow MJ; Gaunt HJ; Rubaiy HN; Musialowski KE; Blythe NM; Vasudev NS; Muraki K; Beech DJ J. Biol. Chem 2017, 292, 723-731. [PubMed: 27875305]

(67). Rodrigues T; Sieglitz F; Somovilla VJ; Cal PM; Galione A; Corzana F; Bernardes GJ Angew. Chem., Int. Ed 2016, 55, 11077-11081.

(68). Grohar PJ; Woldemichael GM; Griffin LB; Mendoza A; Chen QR; Yeung C; Currier DG; Davis S; Khanna C; Khan J; McMahon JB; Helman LJ J. Natl. Cancer Inst 2011, 103, 962- 978. [PubMed: 21653923]

(69). Teicher BA; Polley E; Kunkel M; Evans D; Silvers T; Delosh R; Laudeman J; Ogle C; Reinhart R; Selby M; Connelly J; Harris E; Monks A; Morris J Mol. Cancer Ther 2015, 14, 2452- 2462. [PubMed: 26351324]

(70). Brohl AS; Solomon DA; Chang W; Wang J; Song Y; Sindiri S; Patidar R; Hurd L; Chen L; Shern JF; Liao H; Wen X; Gerard J; Kim JS; Lopez Guerrero JA; Machado I; Wai DH; Picci P; Triche T; Horvai AE; Miettinen M; Wei JS; Catchpool D; Llombart-Bosch A; Waldman T; Khan J PLoS Genet 2014, 10, e1004475. [PubMed: 25010205]

(71). Mathews Griner LA; Guha R; Shinn P; Young RM; Keller JM; Liu D; Goldlust IS; Yasgar A; McKnight C; Boxer MB; Duveau DY; Jiang JK; Michael S; Mierzwa T; Huang W; Walsh MJ; Mott BT; Patel P; Leister W; Maloney DJ; Leclair CA; Rai G; Jadhav A; Peyser BD; Austin CP; Martin SE; Simeonov A; Ferrer M; Staudt LM; Thomas CJ Proc. Natl. Acad. Sci. U. S. A 2014, 111, 2349-2354. [PubMed: 24469833]

(72). Neckers LM; Sourbier CAC; Linehan WM; Neckers JB; Lee MJ; Scroggins BT; Beutler JA U.S. Pat. 9,101,601, 2015.

(73). Neckers LM; Sourbier C; Neckers JB; Lee MJ; Beutler JA; Linehan WM; Scroggins BT; Lee SU.S. Pat. 9,517,224, 2016. 
(74). Gutierrez C; Serrano-Villar S; Madrid-Elena N; Perez-Elias MJ; Martin ME; Barbas C; Ruiperez J; Munoz E; Munoz-Fernandez MA; Castor T; Moreno S AIDS 2016, 30, 1385-1392. [PubMed: 26891037]

(75). Beans EJ; Fournogerakis D; Gauntlett C; Heumann LV; Kramer R; Marsden MD; Murray D; Chun TW; Zack JA; Wender PA Proc. Natl. Acad. Sci. U. S. A 2013, 110, 11698-11703. [PubMed: 23812750]

(76). Gustafson KR; Cardellina JH, II; McMahon JB; Gulakowski RJ; Ishitoya J; Szallasi Z; Lewin NE; Blumberg PM; Weislow OS; Beutler JA; Buckheit RW; Cragg GM; Cox PA; Bader JP; Boyd MR J. Med. Chem 1992, 35, 1978-1986. [PubMed: 1597853]

(77). Hezareh M; Moukil MA; Szanto I; Pondarzewski M; Mouche S; Cherix N; Brown SJ; Carpentier JL; Foti M Antiviral Chem. Chemother 2004, 15, 207-222.

(78). Beutler JA; Ratnayake R; Johnson T; Covell DG U.S. Pat. 8,410,292, 2013.

(79). Beutler JA; Ratnayake R; Covell DG; Johnson TR European Pat. Appl. EP 2235021 B1, 2012.

(80). Beutler JA; Ratnayake R; Covell DG; Ransom TT Japanese Pat 5547653, 2014.

(81). Johnson T; Ratnayake R; Beutler JA; Covell DG Australian Pat 2008347299, 2013.

(82). Echavarren AM; Molawi K; Delpont NPR WIPO Appl 2011/120886, 2011.

(83). Chain WJ; Beutler JA; Fash DM; Figg WD; Li Z; Peer CJ; Ramos JW; Sulzmaier FJ U.S. Pat. Appl. 62/018,381, 2016.

(84). Beutler JA; Echavarren AM; Lopez L; Bravo F; Riesgo L; Ransom TT U.S. Pat. Appl. 62/146,805, 2015.

(85). Nath PR; Isakov N Biochem. Soc. Trans 2014, 42, 1484-1489. [PubMed: 25399558]

(86). Altman A; Villalba MJ Biochem 2002, 132, 841-846.

(87). Duensing A; Joseph NE; Medeiros F; Smith F; Hornick JL; Heinrich MC; Corless CL; Demetri GD; Fletcher CD; Fletcher JA Cancer Res 2004, 64, 5127-5131. [PubMed: 15289315]

(88). Belguise K; Sonenshein GE J. Clin. Invest 2007, 117, 4009-4021. [PubMed: 18037997]

(89). Villalba M; Altman A Curr. Cancer Drug Targets 2002, 2, 125-137. [PubMed: 12188914]

(90). Boschelli DH Curr. Top. Med. Chem 2009, 9, 640-654. [PubMed: 19689371]

(91). Freichel M; Tsvilovskyy V; Camacho-Londono JE Handb. Exp. Pharmacol 2014, 222, 85-128. [PubMed: 24756704]

(92). Zeng B; Yuan C; Yang X; Atkin SL; Xu SZ Curr. Cancer Drug Targets 2013, 13, 103-116. [PubMed: 22920441]

(93). Veliceasa D; Ivanovic M; Hoepfner FT; Thumbikat P; Volpert OV; Smith ND FEBS J 2007, 274, 6365-6377. [PubMed: 18021253]

(94). Vanden Abeele F; Lemonnier L; Thebault S; Lepage G; Parys JB; Shuba Y; Skryma R; Prevarskaya NJ Biol. Chem 2004, 279, 30326-30337.

(95). Rodrigues T; Sieglitz F; Bernardes GJ Chem. Soc. Rev 2016, 45, 6130-6137. [PubMed: 26890476]

(96). Gaunt HJ; Vasudev NS; Beech DJ Eur. Biophys. J 2016, 45, 611-620. [PubMed: 27289383]

(97). Pfeffer TJ; Sasse F; Schmidt CF; Lakamper S; Kirschning A; Scholz T Eur. J. Med. Chem 2016, 112, 164-170. [PubMed: 26896705]

(98). Bon RS; Beech DJ Br. J. Pharmacol 2013, 170, 459-474. [PubMed: 23763262] 
$\begin{array}{lllllllllll}3.8 & 1.3 & 2 & 2.1 & 3.8 & 4.4 & 8.3 & 25.3 & 71.4 & 100 & 20000.0\end{array}$

$\begin{array}{llllllllll}3 & 1.2 & 1.4 & 2.2 & 4.1 & 5 & 14.3 & 37.4 & 81.9 & 100\end{array}$

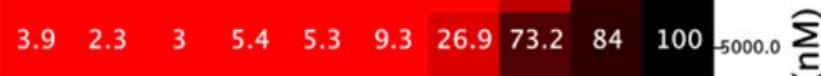

$\begin{array}{llllllllllll}5.2 & 4.2 & 4.4 & 5.3 & 7.3 & 18.9 & 62.9 & 77.3 & 95.7 & 100 & 2500.0 & \varangle\end{array}$

$\begin{array}{lllllllllllll}7.5 & 4.9 & 4.7 & 12.1 & 17.7 & 43.1 & 71.2 & 85.7 & 94.4 & 100 & 4250.0 & & \end{array}$

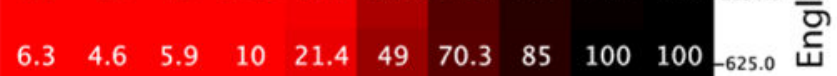

$\begin{array}{lllllllllll}7.6 & 6.4 & 11.3 & 15.4 & 26.4 & 58.3 & 82.5 & 100 & 100 & 100 & -312.5\end{array}$

$\begin{array}{lllllllllll}7.6 & 6.8 & 8.2 & 13 & 26.2 & 59.4 & 80.6 & 92.4 & 100 & 100 & -156.25\end{array}$

$\begin{array}{llllllllll}9.8 & 6.7 & 8 & 13.7 & 30.8 & 64.9 & 99.6 & 100 & 92.1 & 91.5\end{array}-78.13$

$\begin{array}{lllllllllll}12.8 & 9.7 & 11.9 & 18.6 & 30.3 & 65.6 & 96.9 & 100 & 100 & 100 & 0.0\end{array}$

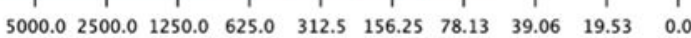

Sepantronium $\mathrm{Br}(\mathrm{nM})$

A

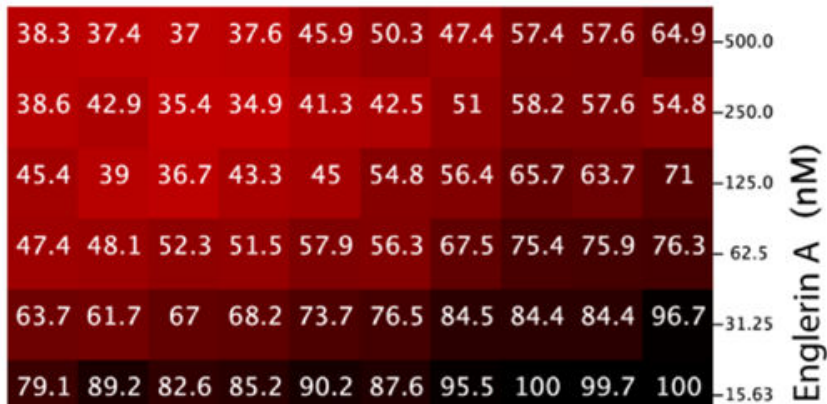

$\begin{array}{lllllllllll}91.2 & 89.2 & 86.6 & 98.6 & 87.1 & 93.9 & 95.4 & 100 & 100 & 94.3 & -7.81\end{array}$

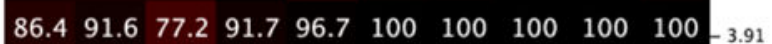

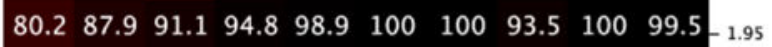

$\begin{array}{llllllllllll}85.9 & 82.4 & 88.6 & 80.3 & 93.5 & 97.6 & 100 & 100 & 100 & 97.3 & 0.0\end{array}$

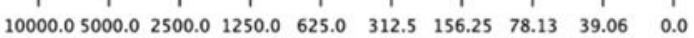

B

\section{Figure 1.}

Isobolograms from drug combination studies ${ }^{71}$ with englerin A combined with (A) septantronium bromide in UOK121 kidney cancer cells or (B) ABT-263 in TC71 Ewing's sarcoma cells. Full data are contained in Table S2, Supporting Information. 


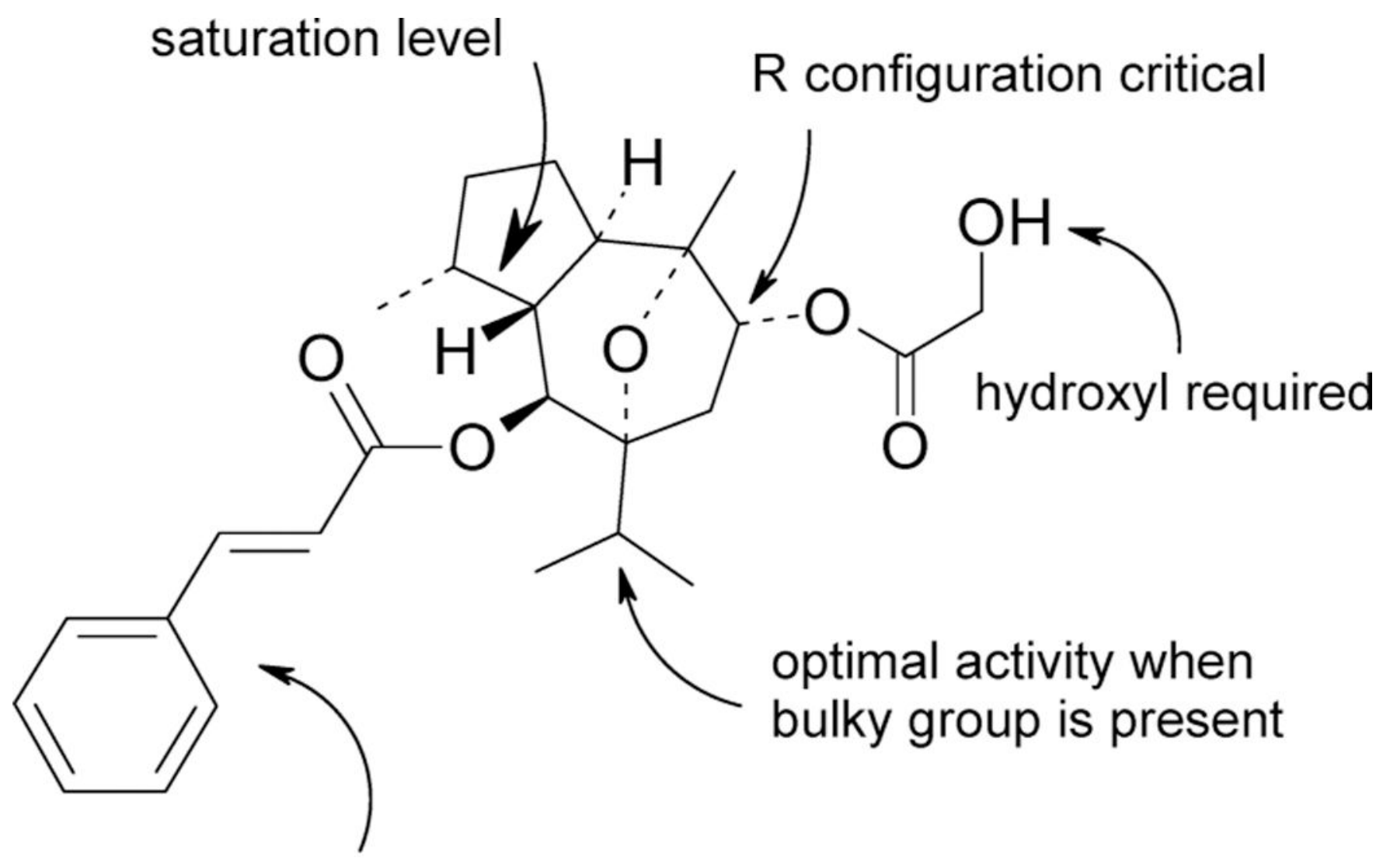

hydrophobic group optimal

Figure 2.

Important structure-activity factors in englerin analogue biological activity. 


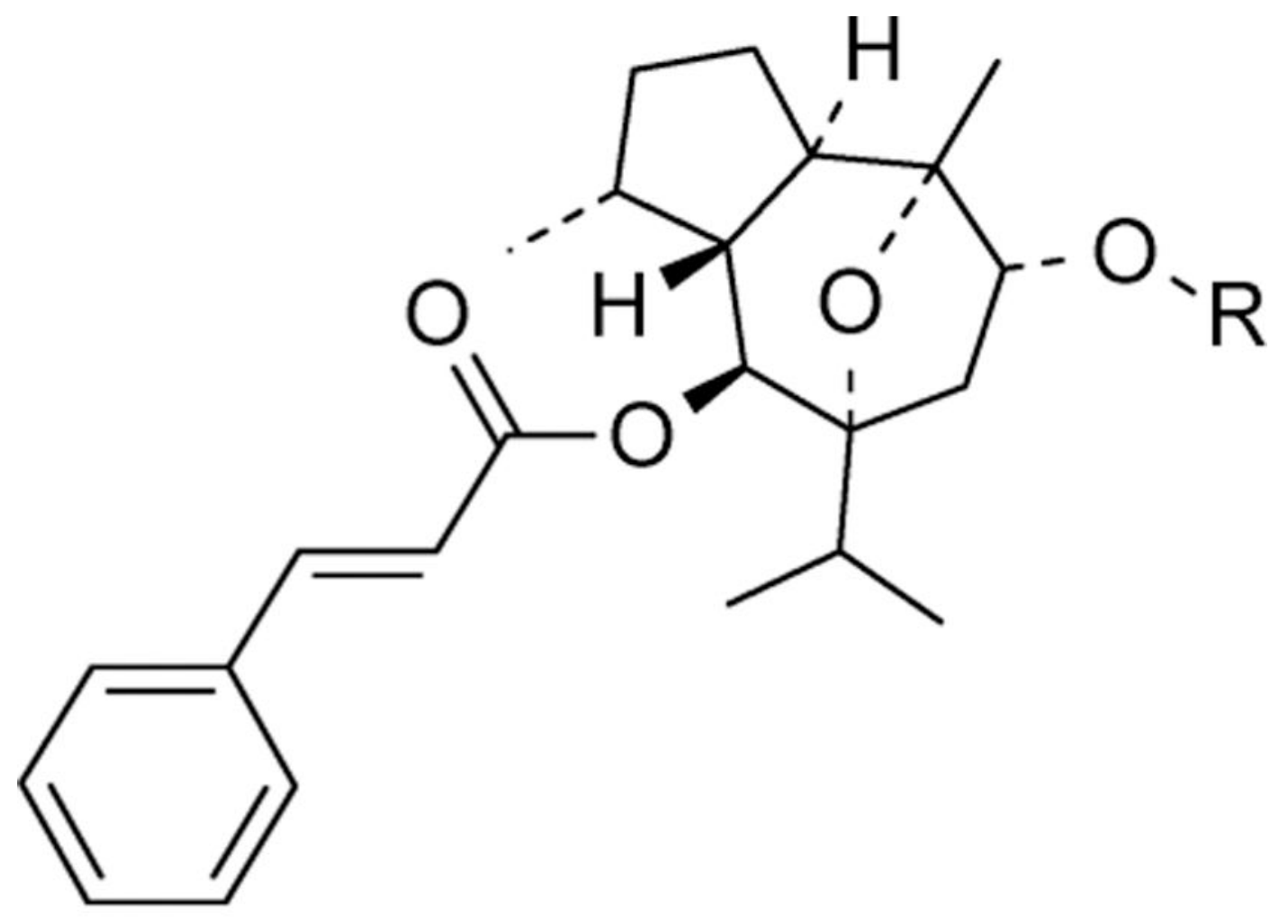

Chart 1.

Structure of the Natural (-)-Englerins A and B and Englerin B Acetate 

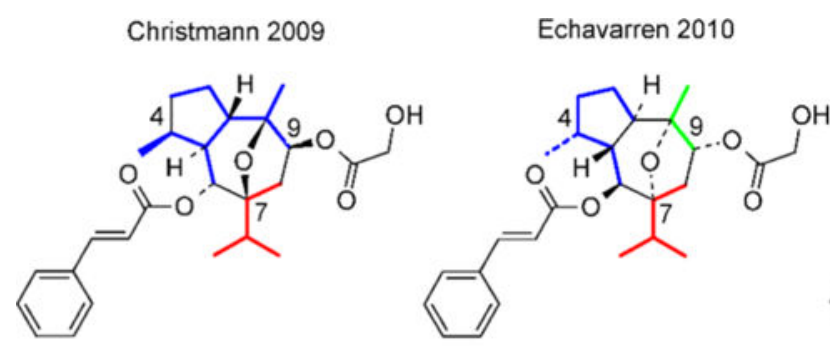

Ma, 2010, Hatakeyama 2012
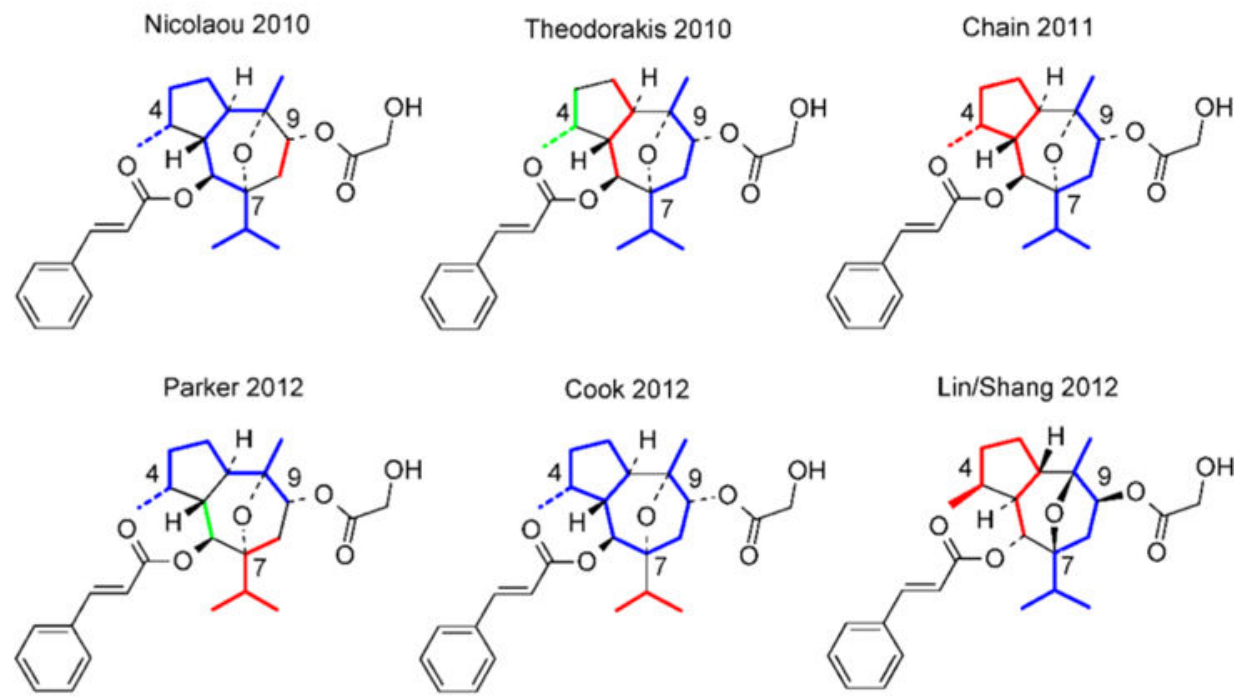

Lin/Shang 2012

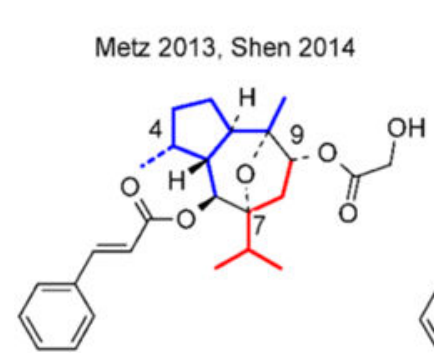

Anada/Hashimoto 2015 Iwasawa 2016
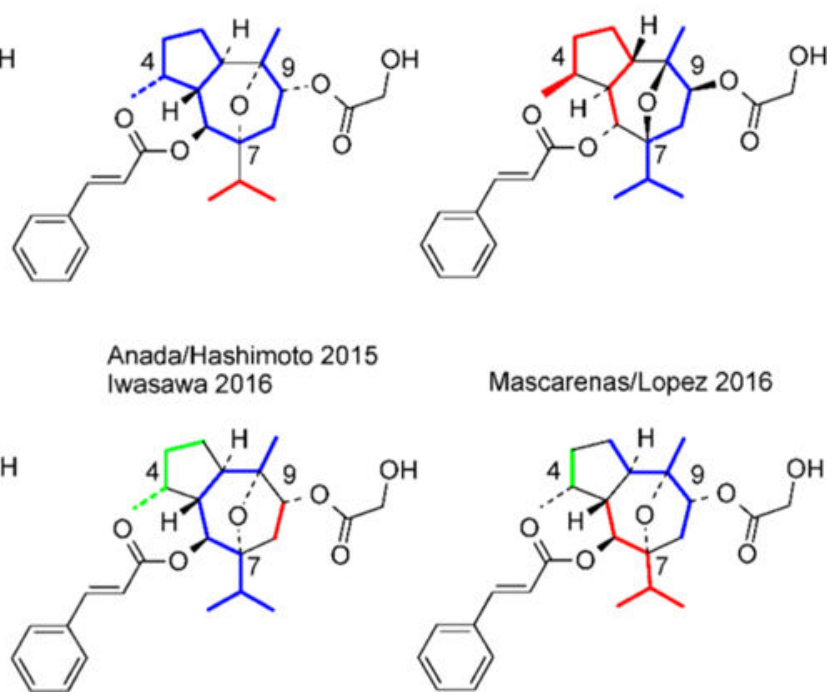

Mascarenas/Lopez 2016

Chart 2.

Diversity of Englerin Total Synthetic Skeleton Disconnections 
Wu et al.

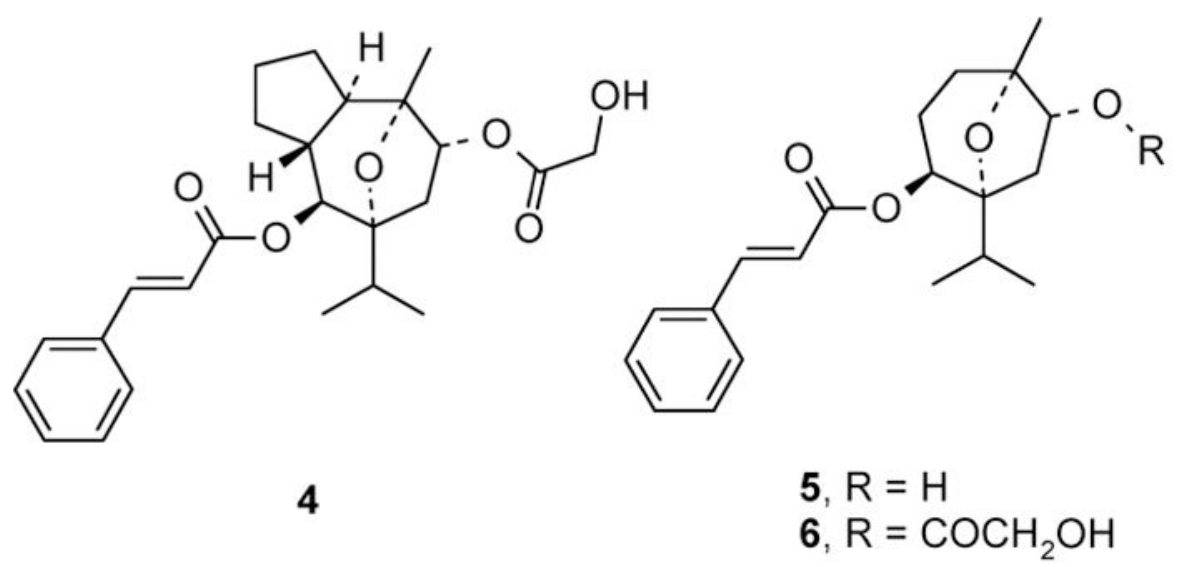

Page 24

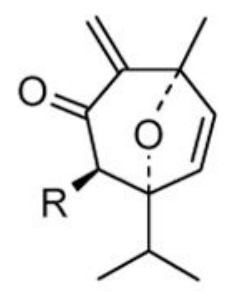

7, $\mathrm{R}=\mathrm{H}$

8, $\mathrm{R}=\mathrm{OH}$

9, $\mathrm{R}=\mathrm{OAC}$

10, $R=$ Benzoyl

11, $R=$ Cinnamoyl

Chart 3.

Radical Core Reductions of the Englerin Skeleton 


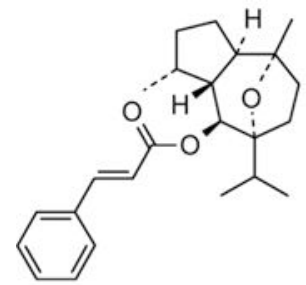

12

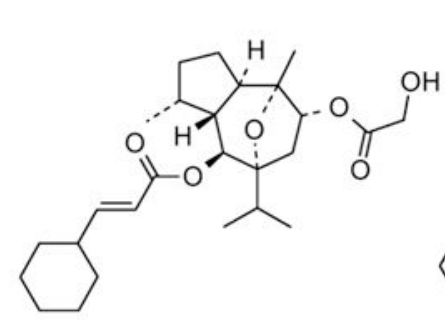

22

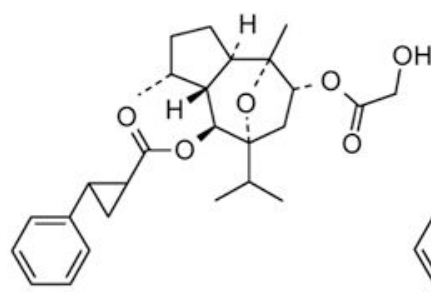

25

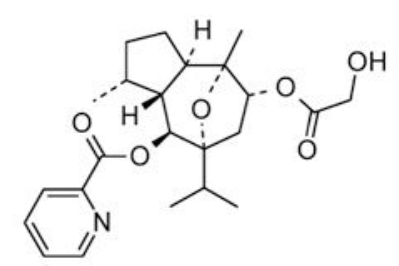

32

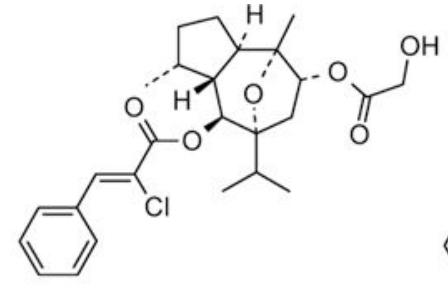

13

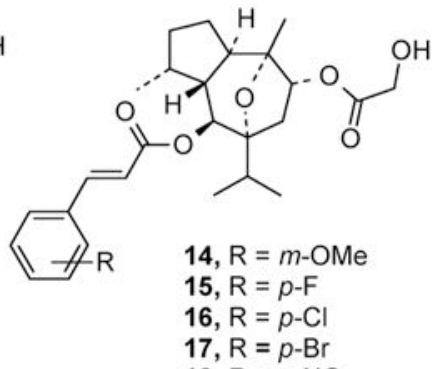

18, $\mathrm{R}=p-\mathrm{NO}_{2}$

19, $\mathrm{R}=p-\mathrm{iPr}$

20, $R=3,4$-methylenedioxy-

21, $\mathrm{R}=1-\mathrm{F}, 5-\mathrm{Cl}$

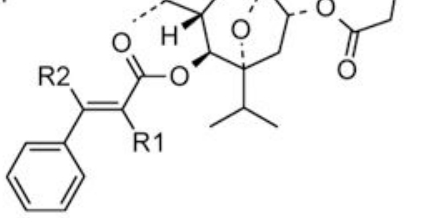

23, $\mathrm{R}_{1}=\mathrm{Me}, \mathrm{R}_{2}=\mathrm{H}$

24, $R_{1}=H, R_{2}=M e$

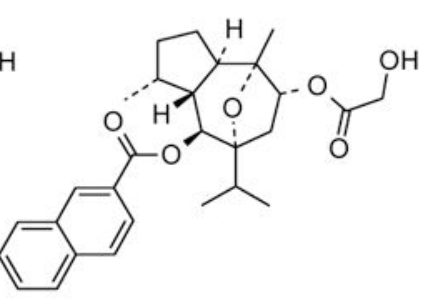

26

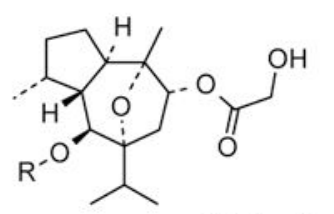

33, $\mathrm{R}=2$-pentenyl

$34, R=A C$

$35, \mathrm{R}=2$-propeny

$36, R=$ tiglyl

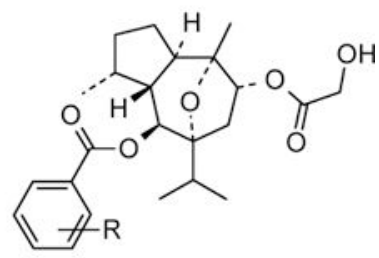

27, $\mathrm{R}=\mathrm{H}$

28, $\mathrm{R}=p-\mathrm{F}$

29, $\mathrm{R}=p-\mathrm{Cl}$

$30, \mathrm{R}=\mathrm{NO}_{2}$

31, $\mathrm{R}=$ 2,4-dichloro-

Chart 4.

Ester Modifications of the Englerin A Structure 
<smiles>[R]C12C[C@H](OC(=O)CO)[C@@](C)(O1)[C@@H]1CC[C@H](C)[C@]1(C)[C@H]2OC(=O)/C=C/c1ccccc1</smiles>

$45 \mathrm{R}=\mathrm{H}$

Chart 5.

Subtle Core Modification
$37 \mathrm{R}=\mathrm{Et}$

$38 \mathrm{R}=\mathrm{Me}$<smiles>[R]C12CC(OC(=O)CO)C(C)(O1)C1=C(C)CC[C@@]12C</smiles>

$39 \mathrm{R}=$ cyclopropyl

$40 \mathrm{R}=$ cyclohexyl

$41 \mathrm{R}=$ phenyl

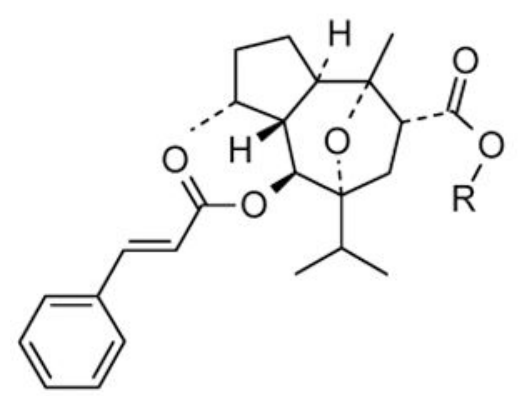

$44 \mathrm{R}=\mathrm{CH}_{2} \mathrm{CH}_{2} \mathrm{OH}$

46

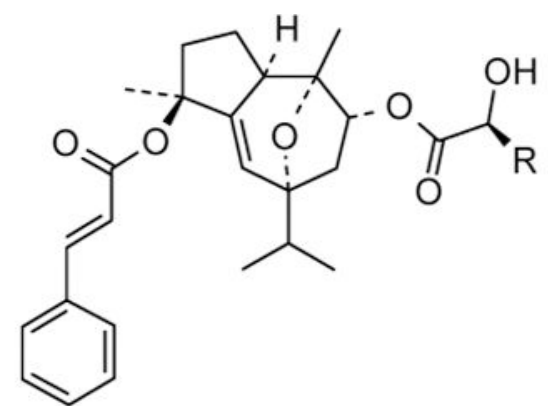

$42 \mathrm{R}=\mathrm{H}$

$43 \mathrm{R}=\mathrm{Me}$

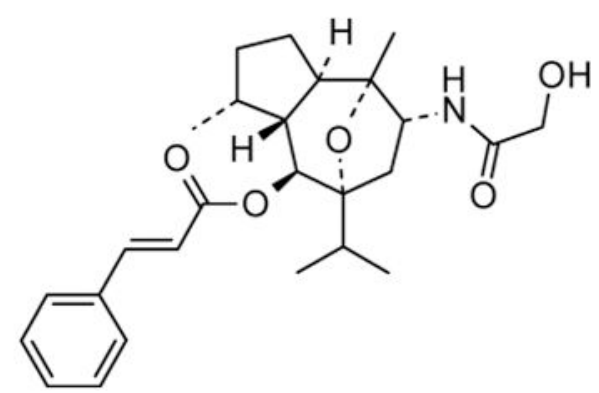

47 
<smiles>CC1(C)C2CC(OC(=O)C=Cc3ccccc3)CC1(C)C(OC(=O)CO)C2</smiles><smiles>[R]c1cccc(C[C@H](NC(=O)OCc2ccccc2)C(=O)OC)c1</smiles><smiles></smiles>

48

49, $R=$ phenyl

53

50, $R=2$-furanyl

51, $\mathrm{R}=66^{\prime}-\mathrm{Cl}, 3$-pyridinyl

52, $\mathrm{R}=6$ '-MeO, 3-pyridinyl

Chart 6.

Scaffold Hopping 
<smiles>C#CCCCC(=O)OCC(=O)OC1CC(C(C)C)C2OC1C1(C)CCC(C)C2(O)C1OC(=O)C=Cc1ccccc1</smiles>
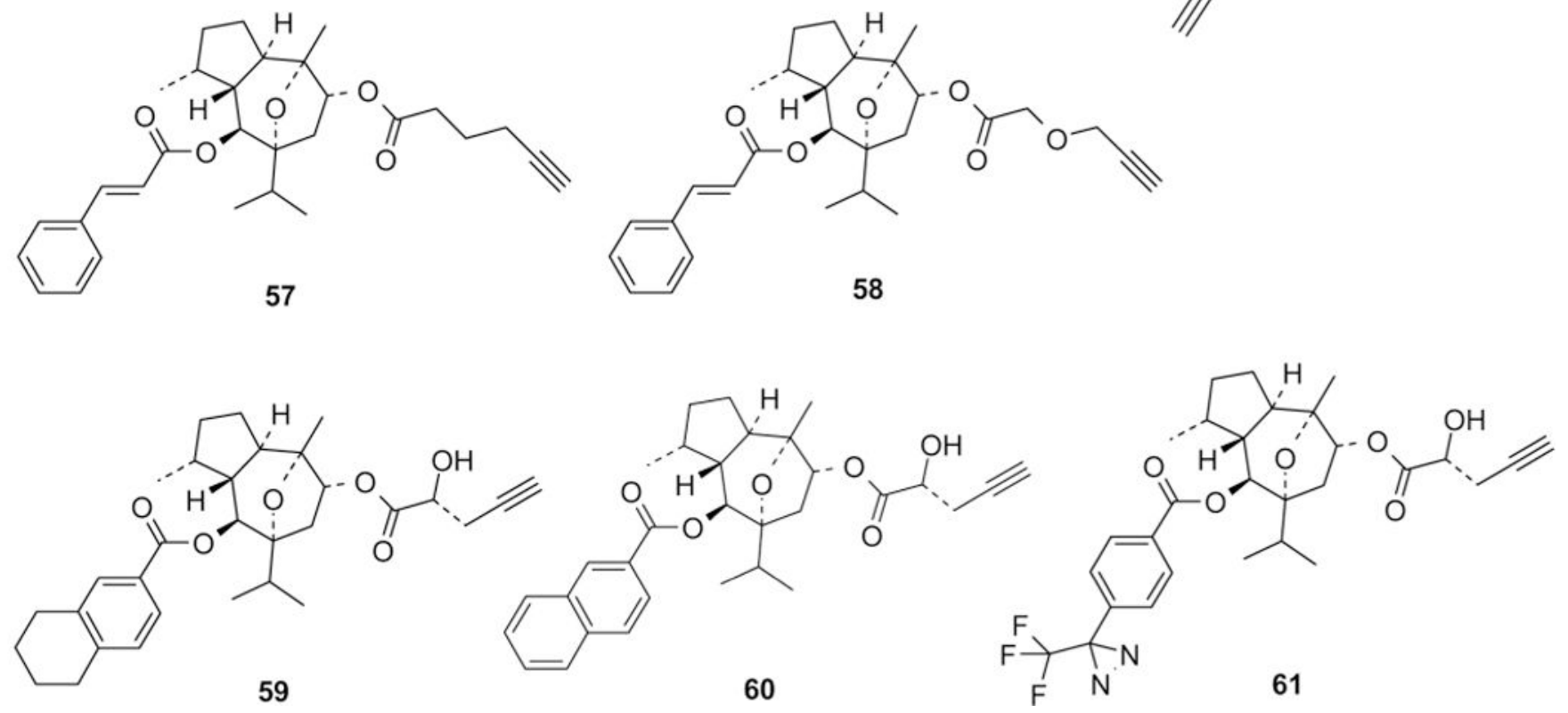

Chart 7.

Englerin Tool Compounds Synthesized by the Christmann Group ${ }^{56}$ 


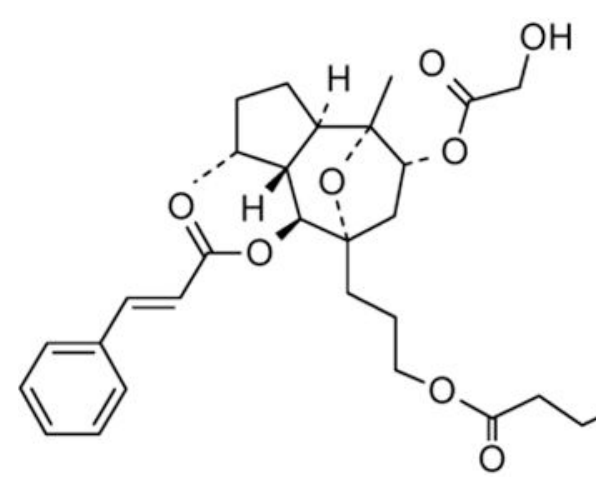

62

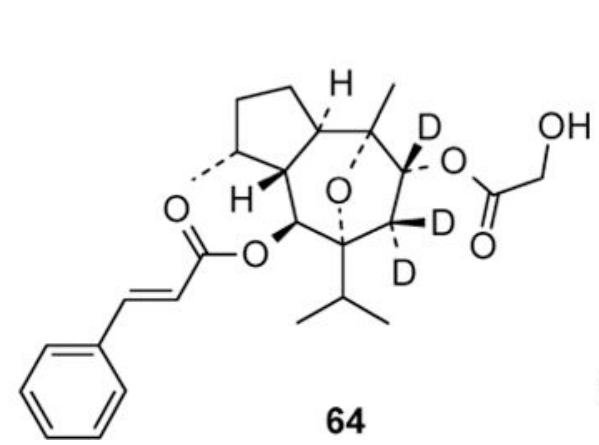

Chart 8.

Tool Compounds Synthesized by the Chain Group
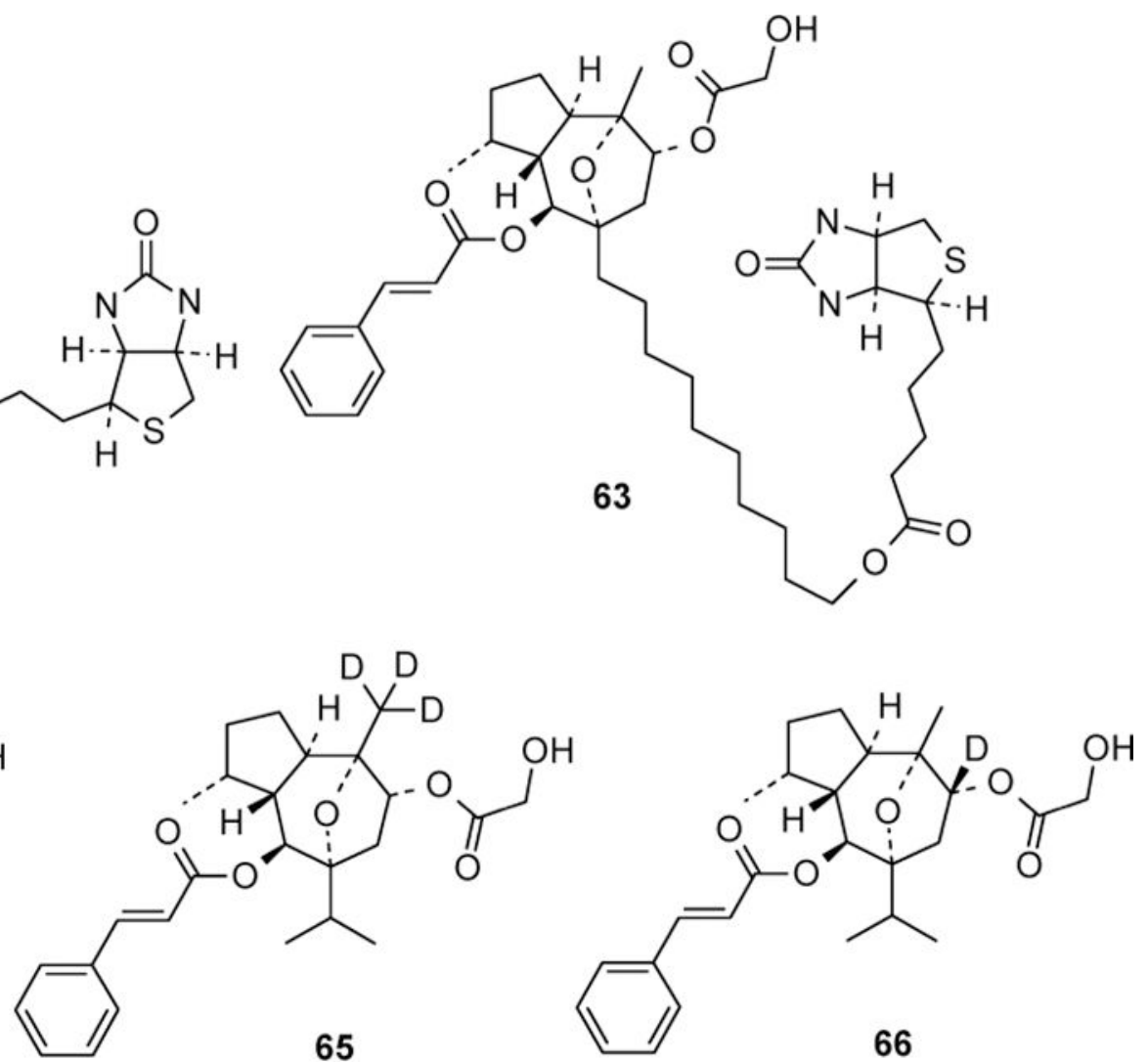

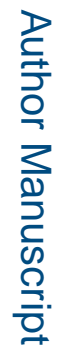

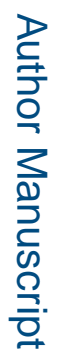


Table 1.

Completed/Formal Total Syntheses of Englerin A

\begin{tabular}{|c|c|c|c|c|c|}
\hline group & date publ. & chirality & $\begin{array}{c}\text { yield } \\
(\%)\end{array}$ & steps & notes \\
\hline Christmann $^{22}$ & 10/30/2009 & + & 10.9 & 15 & \\
\hline Echavarren $^{24}$ & $4 / 6 / 2010$ & - & 7 & 18 & gold \\
\hline $\mathrm{Ma}^{25}$ & $4 / 6 / 2010$ & - & 8.1 & 15 & gold \\
\hline Nicolaou/Chen ${ }^{26}$ & $6 / 16 / 2010$ & \pm & 2.9 & 17 & \\
\hline Theodorakis $^{27}$ & $7 / 29 / 2010$ & - & formal & formal & {$[4+3]$} \\
\hline Christmann $^{23}$ & $3 / 30 / 2011$ & - & 11 & 19 & \\
\hline Chain $^{28}$ & $4 / 8 / 2011$ & - & 20 & 8 & \\
\hline Parker $^{29}$ & $5 / 7 / 2012$ & - & formal & formal & \\
\hline Hatakeyama $^{31}$ & $8 / 7 / 2012$ & - & 14 & 24 & \\
\hline Sun/Lin 33 & $1 / 4 / 2013$ & + & 3.5 & 12 & \\
\hline Metz $^{34}$ & $4 / 15 / 2013$ & - & 16 & 12 & \\
\hline Shen $^{35}$ & $1 / 10 / 2014$ & - & 11 & 9 & \\
\hline $\begin{array}{l}\text { Hashimoto/ } \\
\text { Anada }^{36}\end{array}$ & $7 / 14 / 2015$ & - & 5.2 & 25 & \\
\hline Iwasawa $^{37}$ & $10 / 8 / 2015$ & \pm & 16.2 & 14 & {$[3+2]$} \\
\hline $\begin{array}{l}\text { Mascareñas/ } \\
\text { Lopeź }^{39}\end{array}$ & $10 / 13 / 2016$ & - & 11 & 17 & {$[4+3]$} \\
\hline
\end{tabular}

J Nat Prod. Author manuscript; available in PMC 2018 October 23. 